\title{
GEOLOGICAL-GEOPHYSICAL MODELS OF THE CRUST FOR THE WHITE SEA REGION
}

\author{
N.V. Sharov ${ }^{1 \bowtie}$, L.I. Bakunovich ${ }^{1}$, B.Z. Belashev ${ }^{1}{ }^{1}$, V.A. Zhuravlev² , M.Yu. Nilov ${ }^{1}$
}

${ }^{1}$ Institute of Geology, Karelian Research Centre of the Russian Academy of Sciences, 11 Pushkinskaya St, Petrozavodsk 185910, Russia

${ }^{2}$ JSC Marine Arctic Geological Exploration Expedition, 26 Sofia Perovskaya St, Murmansk 183038, Russia

ABSTRACT. The study of the White Sea region and the adjacent area aimed to model the structure of the crystalline portion of the crust at the contact of the northeastern slope of the Fennoscandian Shield and the Russian Plate. Modeling was based on geological, geophysical and DSS profile data, State Geological Map of the Russian Federation (scale 1:1000000), Explanatory Notes to Sheets Q-35, 36, 37, and 38 (third generation, 2009), and Tectonic Map of the White Sea and Adjacent Areas (2012). A model was constructed using GIS INTEGRO software (VNIIgeosystems), specifically its procedures for calculation and visualization of 2D and 3D models showing crust density and magnetic fields. The model of the study area shows the structure of the crust and the characteristics of its horizons.

KEYWORDS: Fennoscandian Shield; Russian Plate; White Sea; crust; GIS INTEGRO; seismic; density and magnetic models; Moho (M-discontinuity)

FUNDING: The study was carried out under the state assignment of the Institute of Geology of the Karelian Research Center RAS (№ AAAA-A18-118020290086-1) with partial financial support from the RFBR (project № 19-05-00481 Structure and Dynamics of the Lithosphere of the White Sea Region). 


\title{
ГЕОЛОГО-ГЕОФИЗИЧЕСКИЕ МОДЕЛИ ЗЕМНОЙ КОРЫ БЕЛОМОРЬЯ
}

\author{
Н.В. Шаров ${ }^{1}$, Л.И. Бакунович ${ }^{1}$, Б.З. Белашев ${ }^{1}$, В.А. Журавлев ${ }^{2}$, М.Ю. Нилов ${ }^{1}$
}

\author{
${ }^{1}$ Институт геологии КарНЦ РАН, 185910, Петрозаводск, ул. Пушкинская, 11, Россия \\ ${ }^{2} \mathrm{OAO}$ «Морская арктическая геологоразведочная экспедиция», 183038, Мурманск, ул. Софьи Перовской, 26, \\ Россия
}

АНнОТАЦИЯ. Объектом изучения является район Белого моря и прилегающей суши - Беломорье, расположенный на сочленении северо-восточного склона Фенноскандинавского щита и Русской плиты. Цель представляемой работы - составление на основе комплексного анализа геолого-геофизических данных модели строения кристаллической части земной коры региона. Для анализа использованы данные по профилям ГСЗ (глубинное сейсмическое зондирование), материалы Госгеолкарты РФ масштаба 1:1000000 и Объяснительных записок к листам Q-35, 36, 37, 38 (третье поколение, 2009), а также Тектоническая карта Белого моря и прилегающих территорий (2012). Моделирование проводили программным комплексом ГИС «INTEGRO», разработанным отделением ВНИИгеосистем, который включает процедуры, необходимые для расчета плотностных и магнитных моделей и их 2D- и 3D-визуализации. В результате показана структура земной коры, приведены характеристики ее горизонтов.

КЛЮЧЕВЫЕ СЛОВА: Фенноскандинавский щит; Русская плита; Белое море; земная кора; сейсмическая модель; плотностная модель; магнитная модель; граница Мохоровичича

ФИНАНСИРОВАНИЕ: Работа выполнена в рамках государственного задания ИГ КарНЦ РАН тема НИР ААААА18-118020290086-1, частично профинансирована РФФИ в рамках научного проекта № 19-05-00481 «Строение и динамика литосферы Беломорья».

\section{1. ВВЕДЕНИЕ}

Объектом исследования является бассейн Белого моря, находящийся на сочленении северо-восточного склона Фенноскандинавского щита и Русской плиты. Акватория моря и прилегающей суши носит название Беломорский регион, или Беломорье. Считается, что структура сформировавшихся здесь в архее докембрийских блоков континентальной коры региона сохранилась до настоящего времени. Подтверждением тому является совпадение источников крупных аномалий гравитационного и магнитного полей Фенноскандинавского щита и различие в форме и положениях аномалий северо-западной части Мезенской синеклизы. Последний факт свидетельствует о процессах протерозойского рифтогенеза и последующей тектономагматической активизации на северо-восточном краю Восточно-Европейской платформы. В регионе неоднократно происходило взаимодействие баренцевоморского и скандинавского ледниковых покровов, размеры которых значительно изменялись в ледниковые эпохи плейстоцена. Циклическая смена оледенений и межледниковий вызывала масштабные, до 150 м, колебания уровня Мирового океана, миграцию положения линии шель $\phi-$ континент на сотни километров, кардинальные изменения условий седименто- и морфогенеза, отразившиеся на строении осадочного чехла региона.

Благодаря геолого-геофизическим исследованиям акватории Белого моря и прилегающей территории, за последние годы появились новые данные о глубинном строении Беломорья [Kazanin et al., 2006; Kheraskova et al., 2006; Aplonov, Fedorov, 2006; Zhuravlev, 2007;
Zhuravlev, Shipilov, 2008; Lisitsyn et al., 2017; Kutinov et al., 2019]. В 2002-2004 гг. «Севморгео» совместно с «Невскгеология», ИГ КарНЦ РАН завершила глубинные сейсмические исследования на опорном профиле суша - море 4В и 3-АР (Калевала - Кемь - Белое море Канин Нос). Методической базой исследований был комплексный подход, включающий детальное структурногеологическое картирование, сопоставление геологических и геофизических данных, применение широкого спектра петрологических исследований [Sharov et al., 2005, 2010].

Результаты этих и других современных исследований меняют известные представления о строении земной коры региона. В частности, это касается описания тектонического строения районов Белого и южной части Баренцева моря, приведенного в монографии [Ваluev et al., 2012] и представляющего пояснительную записку к тектонической карте региона, изданной в 2010 г, синтезирующей данные исследований последних лет.

Получение новых и уточнение имеющихся данных о глубинном строении литосферы региона актуально в связи с развитием работ по освоению арктических территорий. В этом плане интерес, проявляемый к Беломорью, определяется наличием развитой инфраструктуры и разрабатываемых месторождений алмазов им. М.В. Ломоносова и им. В.В. Гриба. Хотя последнее промышленное месторождение алмазов в регионе было открыто более 20 лет назад, потенциал открытия новых месторождений сохраняется.

В статье выполнен анализ сейсмических, петрофизических, геотермических, гравиметрических данных, 


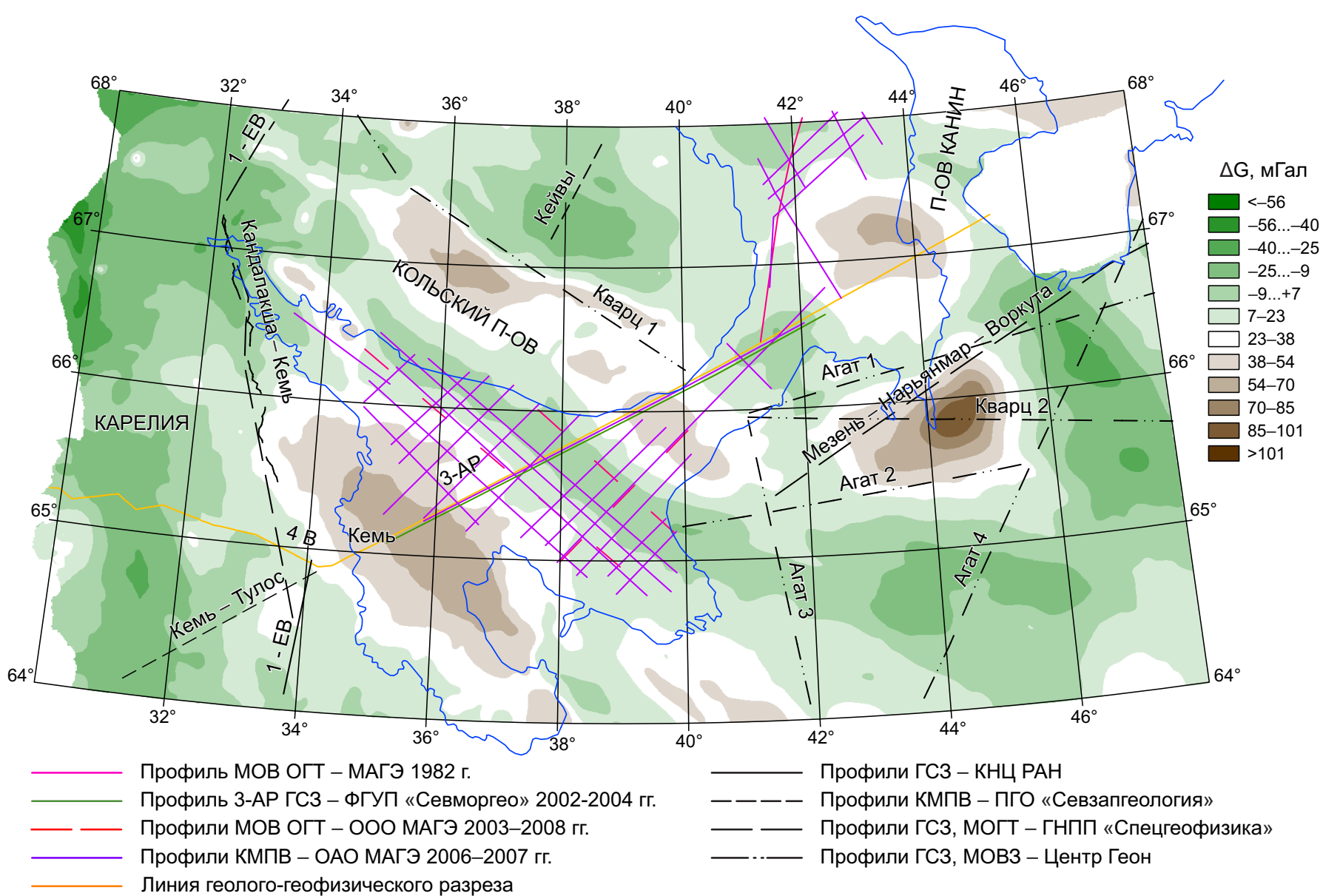

Рис. 1. Схема расположения сейсмических профилей и региональная составляющая гравитационного поля в акватории Белого моря и на прилегающих территориях.

Fig. 1. Schematic map of the White Sea region and the adjacent areas, showing locations of seismic profiles and the regional constituent of the gravity field.

относящихся к Беломорью; проведена их комплексная интерпретация; описаны методические подходы к построению 3D-моделей литосферы региона и результаты их применения.

\section{2. ИСХОДНЫЕ ДАННЫЕ}

Исследование опирается на данные гравиметрических и магнитных съемок, представленные картами масштаба 1:1000000, сейсмические материалы разных лет [Sapozhnikov, 2003; Sharov, 2004; Sharov et al., 2005; Erinchek, 2007; Baluev et al., 2009; State Geological Map..., 2009a, 2009b, 2009c]. При построении геологических моделей среды использованы результаты геофизических исследований (рис. 1) вдоль геотраверсов 3-АР, 1-ЕВ, КВАРЦ, АГАТ и др., привлекались сводные геологогеофизические карты и схемы [Zhuravlev, Shipilov, 2007, 2008; Baluev et al., 2012, 2018].

Построение сейсмоплотностной модели земной коры региона проводилось на основе четырехслойной скоростной модели земной коры [Mitrofanov et al., 1998; Glaznev, 2003; Sharov, 2017] со следующими характеристиками: осадочный слой $V_{\mathrm{p}}=3.4-5.7$ км/с, $\rho=1.90-$ 2.60 г $/ \mathrm{cm}^{3}$; верхний слой (верхний этаж) $-V_{\mathrm{p}}=5.90-$
6.20 км $/$ с, $\rho=2.60-2.75$ г $/ \mathrm{cm}^{3} ;$ средний $-V_{p}=6.30-6.50$ км $/ \mathrm{c}$, $\rho=2.75-2.90$ г $/ \mathrm{cm}^{3} ;$ нижний $-V_{\text {p }}=6.60-6.80$ км $/ \mathrm{c}, \rho=2.90-$

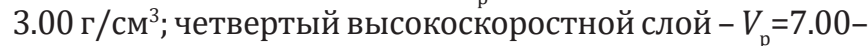
$7.30 \mathrm{\kappa м} / \mathrm{c}, \rho=3.00-3.20$ г $/ \mathrm{cm}^{3}$; мантия $-V_{\mathrm{p}}=8.00-8.20 \mathrm{\kappa м} / \mathrm{c}$, $\rho=3.40 г / \mathrm{cm}^{3}$.

Сводная характеристика слоев модели среды приведена в табл. 1, где, наряду со значениями средней скорости продольных волн в слоях, показан диапазон глубинного положения геологических и сейсмических границ в коре изучаемого региона.

Таблица 1. Усредненная скоростная модель земной коры региона

Table 1. Average velocity model of the crust (White Sea region)

\begin{tabular}{lcc}
\hline Слой коры & $\begin{array}{c}\text { Средняя } \\
\text { скорость, км/с }\end{array}$ & $\begin{array}{c}\text { Диапазон } \\
\text { Глубин, Км }\end{array}$ \\
\hline Осадочный & 4.55 & $0-10$ \\
Гранитно- & 6.13 & $0-20$ \\
метаморфический К1 & 6.65 & $20-32$ \\
Гранулит-базитовый К2 & 7.21 & $30-44$ \\
Переходный & 8.13 & \\
коромантийный К3 & & \\
Верхняя мантия & &
\end{tabular}


В результате обобщения сейсмических данных и сейсмогравитационного моделирования построен четырехслойный разрез земной коры с выделенными осадочным чехлом, верхней, средней и нижней корой.

Обработку и анализ данных проводили программным комплексом ГИС «INTEGRO», разработанным отделением ВНИИгеосистем, содержащим процедуры, необходимые для расчета плотностных и магнитных моделей и их 2D- и 3D-визуализации [Cheremisina et al., 2018].

\section{3. ПОВЕРХНОСТЬ МОХОРОВИЧИЧА}

Согласно сейсмическим данным, отражающим глубинное строение сухопутной части Беломорья, поверхность Мохоровичича (ПМ) является наиболее выраженной сейсмической границей, создающей устойчивые отраженные, преломленные и обменные волны, удобным сейсмическим репером, наносимым на карты в виде системы изогипс. Когда сейсмические данные отсутствуют, оценки мощности земной коры получают, используя корреляционные соотношения между глубиной залегания ПМ, топографией и аномалиями Буге [Kashubin et al., 2011].

Данные о региональном гравитационном поле и рельефе поверхности и глубине залегания ПМ, полученной по сейсмическим профилям, использованы при построении регрессионной зависимости, связывающей эти величины. Задействованы данные по 215 точкам, относящимся к суше, и 55 - к акватории Белого моря.

Чтобы избежать проблем с нарушением непрерывности при переходе от суши к морю, данные рассматривались совокупно. Полученная в результате линейной регрессии зависимость (рис. 2), связывающая глубину залегания ПМ $\left(Z_{M}\right.$, км) с аномалией силы тяжести $(G$, мГал) и отметкой рельефа $(h, \mathrm{M})$, имеет вид:

$$
Z_{M}=39.54-0.0354 G-0.0071 h .
$$

При низких коэффициентах множественной корреляции и детерминации $\mathrm{R}=0.42$ среднеквадратичная ошибка отклонения данных от плоскости, описываемой уравнением регрессии, составила около 2 км. Низкое значение коэффициента корреляции может объясняться уровнем точности определения положения границы Мохо по сейсмическим данным \pm 2 км и разными типами корреляционной связи между глубиной поверхности Мохо, наблюденным гравитационным полем и рельефом.

Схема мощности земной коры по сейсмоплотностным данным приведена на рис. 3. Диапазон изменения мощности земной коры в регионе составляет от 30 до 45 км. Согласно данным глубинной сейсморазведки, минимальная мощность земной коры проявлена в северо-восточной части Мезенской синеклизы. Утонение коры подтверждают обнаруженные здесь две крупные положительные гравитационные аномалии. На западе Кольского полуострова мощность земной коры составляет 40-45 км, на востоке - 35-38 км, в Белом море 38-42 км.

Приведенная схема рельефа ПМ дает лишь общее представление. Детали строения могут быть гораздо сложнее, поскольку в отдельных сечениях изменения уровня ПМ оказываются большими.

Проверка показала, что в области допустимых вариаций плотности общий характер поведения нижней границы меняется слабо, наблюдается сходство во
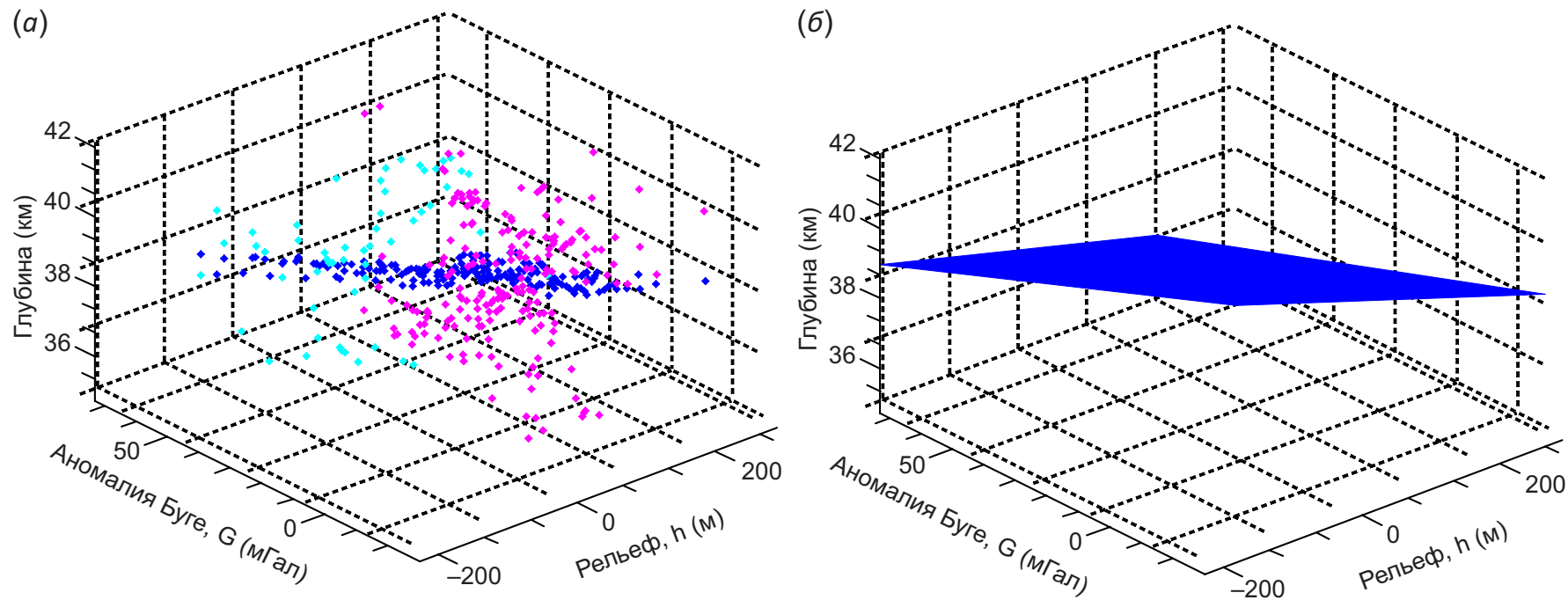

Рис. 2. Данные глубинных сейсмических разрезов и регрессионная модель, связывающая глубину залегания Пм $\left(Z_{M}\right.$, км) с аномалией Буге $(G$, мГал) и отметкой рельефа $(h, \mathrm{~m})$.

Исходные данные, относящиеся к суше и морю, выделены соответственно розовым и голубым цветом, модельные результаты - синим цветом $(a)$, положение регрессионной плоскости границы Мохо в заданной системе координат (б).

Fig. 2. Data of DSS profiles, and a regression model connecting the M-surface depth $\left(Z_{M^{\prime}}\right.$ km), Bouguer anomaly $(G, \mathrm{mGl})$, and elevations $(h, \mathrm{~m})$.

The source data on land and sea areas are highlighted in pink and blue, respectively; the model results are shown in deep blue (a); the Moho regression plane in the specified coordinate system (б). 
взаимоположении внутрикоровых границ и ПМ в широкой области эквивалентных решений. Для локальной составляющей, отражающей распределение плотностных неоднородностей в гранитогнейсовом слое, существенные ограничения, приводящие к устойчивости модели, накладываются при комплексном использовании геолого-геофизических данных.

\section{4. ТЕПЛОВОЙ ПОТОК (ТП)}

Важное научное и практическое значение имеет изучение связи глубинного строения и теплового режима литосферы. Данные ТП позволяют оценить пространственное положение и мощность тепловых источников, судить об энергетике и движущих механизмах развития тектоносферы. На рис. 4 приведены фрагменты карты теплового потока региона. Кольско-Карельская провинция характеризуется низкими значениями ТП (10-50 мВт/м²), что свидетельствует о наличии «холодной» мантии [Tsibulua, Levashkevich, 1992]. Так как изотермическая поверхность температуры Кюри залегает глубже поверхности раздела М, верхние и нижние кромки источников региональных магнитных аномалий (РМА) относят к подошве слоя $\kappa_{1}$ и разделу М соответственно.

В регионе имеет место прямая корреляционная связь между плотностью ТП и толщиной земной коры [Sharov, 2004]. Участки с утоненной корой и приподнятой верхней мантией характеризуются, как правило, пониженными значениями ТП. Корреляция между плотностью ТП и мощностью коры региона указывает на влияние радиогенной теплогенерации в земной коре, отражающей латеральные изменения регионального ТП.

Для зон с низкими скоростями сейсмических волн в верхней мантии наблюдается фоновая плотность ТП. Причинами отсутствия положительных температурных аномалий на земной поверхности могут выступать как малое время действия температурной волны, так и изменение природы волновода, связанное с разуплотнением и изменением состава среды.

\section{5. ПОВЕРХНОСТЬ КРИСТАЛЛИЧЕСКОГО ФУНДАМЕНТА}

Изогипсы дорифейского фундамента, представляющие подошву осадочного чехла, показаны на рис. 5. В осадочном чехле по мощности выделяют области, соответствующие частям Белого моря: бассейну, воронке, горлу, в котором осадочный покров практически отсутствует [Kazanin et al., 2006; Kheraskova et al., 2006]. Средне- и верхнерифейские осадочные и вулканогенные отложения проявлены на побережье Кольского полуострова, в прогибах Беломорской интракратонной зоны акватории Белого моря, в пределах Канинского горста Мезенской синеклизы. Выделенные на суше системы позднепротерозойских (рифейских) рифтогенных прогибов - Беломорская и Мезенская - продолжаются на территории акватории Белого моря. Мезенский грабен и Понойскую впадину в Мезенском заливе

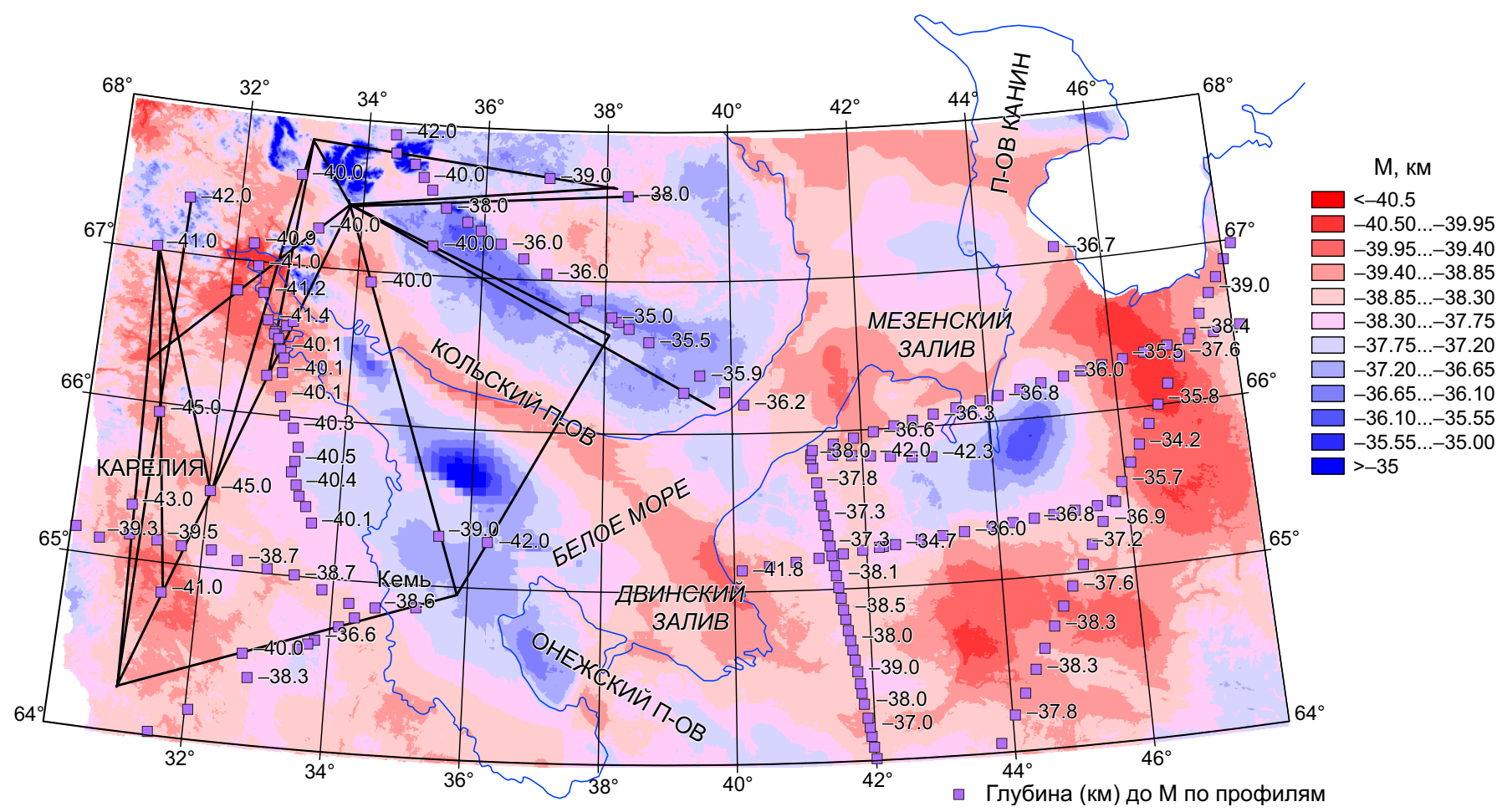

Рис. 3. Сводная карта глубин залегания ПМ, полученная на основе пересчета гравитационного поля, совмещенная с данными по профилям ГСЗ.

Fig. 3. Summary map of the M-surface depths based on recalculations of the gravitational field in combination with the data of DSS profiles. 


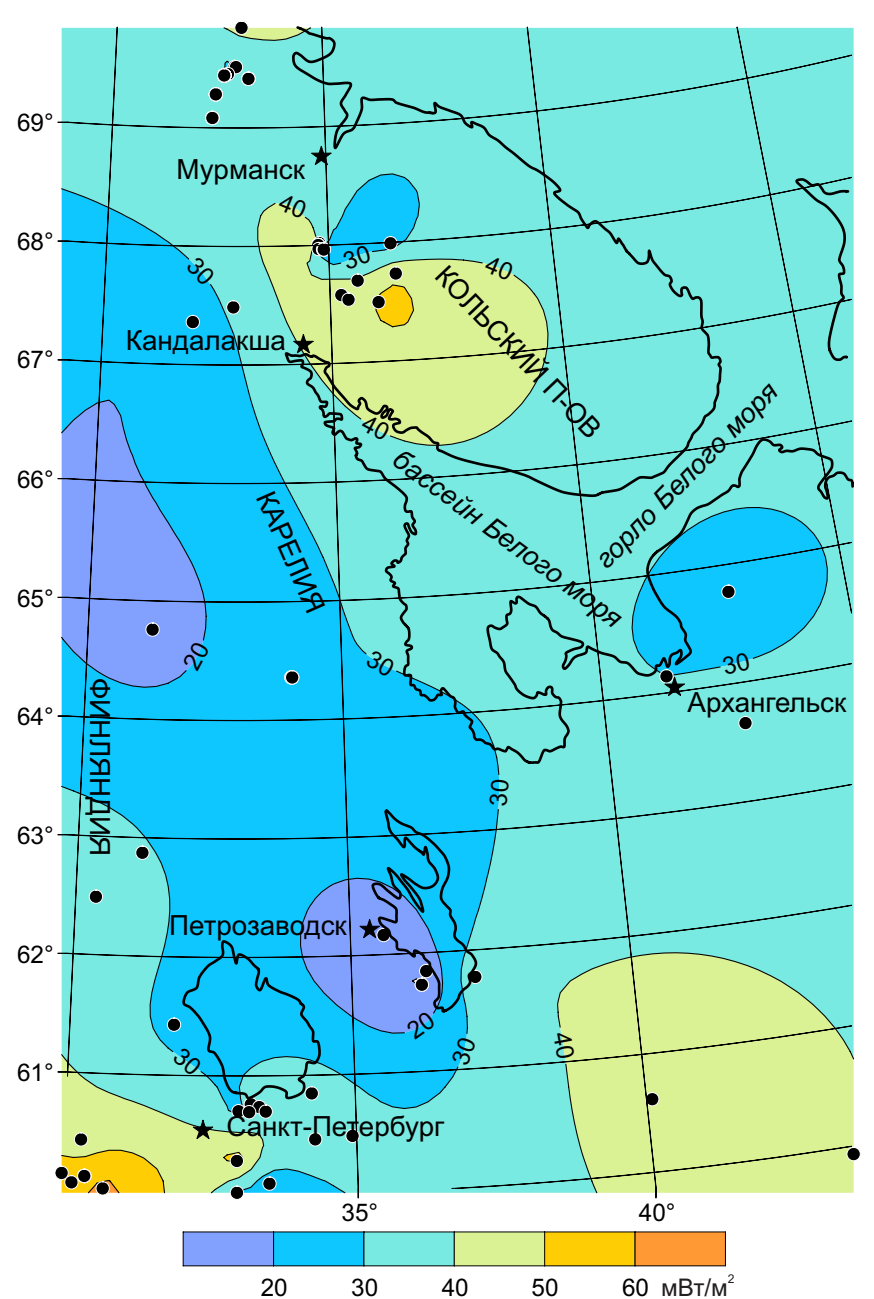

Рис. 4. Схема теплового потока Баренц-региона [Tsibulua, Levashkevich, 1992; Sharov, 2004].

Fig. 4. Heat flow of the Barents region (after [Tsibulua, Levashkevich, 1992; Sharov, 2004]).

и воронке относят к Мезенской рифтовой системе; Кандалакшский, Керецкий, Онежский грабены, связанные с бассейном, - к Беломорской рифтовой системе [State Geological Map..., 2009b, 2009c].

Современные структурные планы осадочных бассейнов воронки Белого моря, по-видимому, сформировались в результате предвендских и последующих тектонических перестроек крупного рифейского седиментационного протобассейна. Для сопоставимых по мощности и стратиграфическому диапазону осадочных разрезов рифейских бассейнов воронки белого моря характерны определенные различия. По сравнению с воронкой внутренний осадочный план Белого моря обособлен, имеет более сложное строение.

В толще осадков бассейна Белого моря выделяют кандалакшский, малошуйско-унский, керецкий комплексы, приуроченные к одноименным грабенообразным прогибам. В Кандалакшском грабене кристаллический фундамент погружен на глубину 8 км, сопоставимую с глубиной Байкальского рифта. В пределах Мезенской синеклизы и в других грабенах рифтовой системы Белого моря глубина залегания кристаллического фундамента достигает 8-10 км и более [Aplonov, Fedorov, 2006; Baluev et al., 2009]. Структурные комплексы осадочного бассейна воронки Белого моря менее сложные. Наиболее мощную толщу осадков имеет Понойская впадина, а толща осадков рифея в ней представлена наиболее полно. Соответствующий сейсмический разрез впадины в целом соответствует описанию толщ рифея в грабенах сухопутной Беломорско-Лешуконско-Мезенской рифтовой системы [Sapozhnikov, 2003; Sharov et al., 2005; Aplonov, Fedorov, 2006], стратификация рифейских отложений которых выполнена по разрезам Усть-Няфтинской и Средненяфтинской скважин. Аналогия с сушей позволяет отнести нижний седиментационный комплекс Понойской впадины к отложениям раннего - среднего рифея, верхний - к позднему рифею. Комплексы верхний $\left(\mathrm{R}_{3}\right)$ и нижний $\left(\mathrm{R}_{1-2}\right)$ пространственно совмещены и перекрывают друг друга. Наибольшая мощность (более 8 км) осадочных образований связана с нижним $\left(\mathrm{R}_{1-2}\right)$ седиментационным комплексом.

Характеризуемый резкими изменениями мощности осадочный чехол воронки перекрывает структурные элементы фундамента: Терскую ступень, Понойскую впадину и Чижский выступ.

\section{6. РЕЗУЛЬТАТЫ ГЕОЛОГО-ГЕОФИЗИЧЕСКОГО 2D-МОДЕЛИРОВАНИЯ ВДОЛЬ ПРОФИЛЕЙ ГСЗ}

Рис. 6, 7, 8, 9 демонстрируют результаты моделирования, выполненного по сейсмическим профилям. На них показано распределение плотности и намагниченности в разрезах земной коры. Они сопровождаются графиками наблюденных, модельных и остаточных аномалий гравитационного и магнитного полей.

Результаты моделирования представлены плотностными моделями вдоль сейсмических профилей 4В (Кемь - Калевала) и 3-АР (Кемь - горло Белого моря) (см. рис. 6), Кандалакша - Кемь (см. рис. 7), участков профилей Кварц 1 и Кварц 2 (Хибины - Варзуга - горло Белого моря - Мезень - р. Цельма) (см. рис. 8), Агат 3 (Усть-Пинега - Белое море) (см. рис. 9). Положение профилей показано на рис. 1. 2D-модели отражают распределение плотности в разрезах земной коры в соответствии с ее делением по сейсмическим данным на четыре слоя, распределение эффективной плотности и магнитных неоднородностей. Подбор плотностного разреза, адекватного наблюденному гравитационному полю, на первом этапе включал определение вклада в гравитационное поле отдельных аномалеобразующих объектов. На разрезах эффективной плотности и намагниченности вынесены границы слоев, картируемые на сейсмических профилях, тектонические нарушения, наблюдаемые и модельные гравитационные поля. Наиболее неоднородной является верхняя часть разрезов до поверхности К1. При этом сопоставление с геологической картой позволяет прослеживать в ряде случаев под отдельными выходами плотных пород на глубине единую область повышенной плотности. 


\section{1. Профили 4В (Кемь - Калевала) и 3-АР (Кемь - горло Белого моря)}

Разрез позволяет изучать структуру земной коры на всю ее мощность, выяснить строение отдельных блоков (террейнов), их соотношение. На нем отчетливо проявлены Карельская, Беломорская и Кольская провинции [Zhuravlev, 2007; Sharov et al., 2010].

Основные структурные элементы Карельской провинции с запада на восток представлены западной частью террейна Кианта, разделенной палеопротерозойской Каллиоярвинской структурой, фрагментами Центрально-Карельского террейна, граничащего с Беломорской провинцией, Шомбозерской структурой, сложенной тектоническими пластинами палеопротерозойских осадочных, вулканогенных и интрузивных пород. Погружающуюся на восток границу между террейном Кианта и западной пластиной Центрально-Карельского террейна (см. рис. 6) считают неоархейским надвигом - свидетельством аккреции более молодого (с возрастом коры 2.80-2.65 млрд лет) Центрально-Карельского террейна к относительно древнему (с возрастом коры 3.10-2.65 млрд лет) континентальному блоку Кианта.
Основание террейна Кианта представлено двумя составляющими: одной с обилием отражающих сейсмических границ и другой, более однородной, подстилающей первую. Сформированные в палеопротерозое рифтогенные Шомбозерская и Каллиоярвинская структуры участвовали в коллизионных процессах при формировании Свекофеннского и Лапландско-Кольского орогенов: континентальная кора Беломорского сегмента была надвинута на Центрально-Карельский по Шомбозерскому шву, а Каллиоярвинской системой рифтогенных разломов Центрально-Карельский террейн был разбит на два (см. рис. 6).

Сейсмоплотностное моделирование разреза профиля 3-АР в Белом море выявило под Кандалакшским и Керецким рифтами магматический очаг, подтвердив результаты исследования [Zhuravlev, 2007]. Прослеживаемый в нижнюю кору очаг может быть связан с мантией. С увеличением глубины его магмоподводящий канал отклоняется к северо-востоку, соответствуя общему падению комплексов пород Беломорского пояса. Для тектонических нарушений в верхней части разреза из-за меньшей пластичности пород характерным является юго-западное или вертикальное падение.

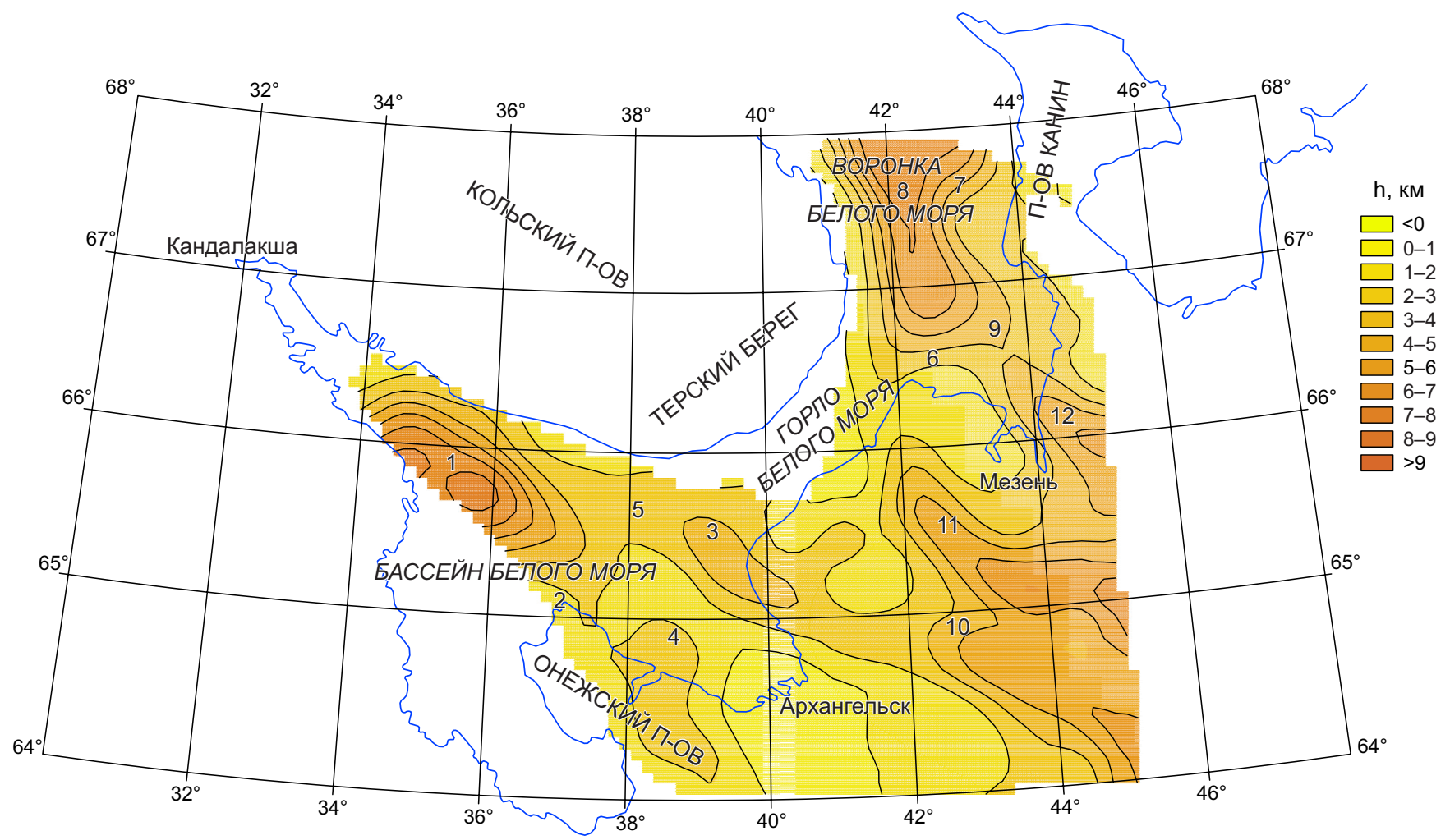

Рис. 5. Структурная схема поверхности гетерогенного фундамента Белого моря и Мезенской рифтовой системы (на основе [Kazanin et al., 2006]).

Цифрами обозначены основные структурные элементы фундамента: 1 - Кандалакшский грабен, 2 - Онежский грабен, 3 Керецкий грабен, 4 - Малошуйско-Унский прогиб, 5 - Терская ступень, 6 - Кулойский выступ, 7 - Чижский выступ, 8 - Понойская впадина, 9 - Мезенский грабен, 10 - Пинежский грабен, 11 - Кулойский грабен, 12 - Усть-Мезенский грабен.

Fig. 5. Structural scheme showing the surface of the heterogenous basement of the White Sea and the Mezen Rift System (after [Kazanin et al., 2006]).

Main structural units: 1 - Kandalaksha graben, 2 - Onega graben, 3 - Keretsky graben, 4 - Maloshuisko-Unsky trough, 5 - Terskaya step, 6 Kuloy ledge, 7 - Chizhsky ledge, 8 - Ponoy depression, 9 - Mezen graben, 10 - Pinega graben, 11 - Kuloy graben, 12 - Ust-Mezen graben. 
(a) $\Delta \mathrm{G}$, мГал

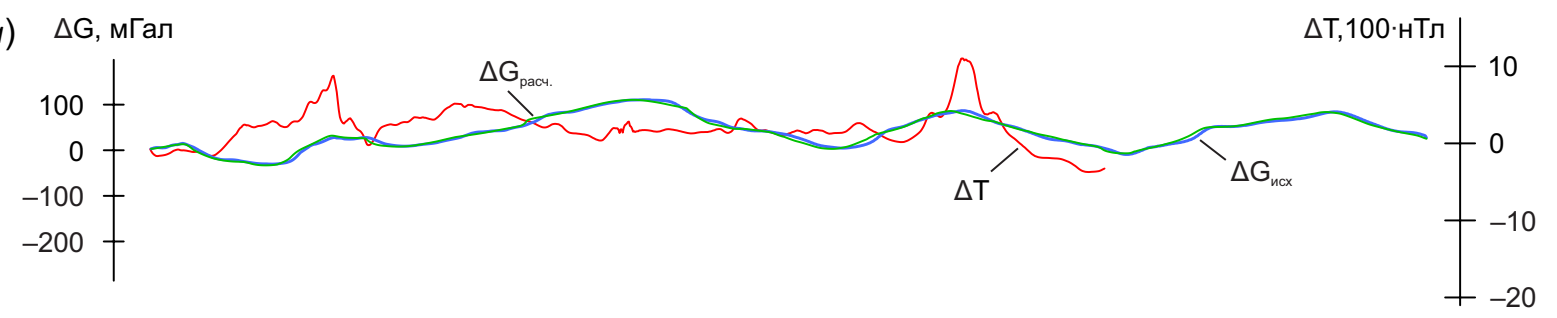

(б)

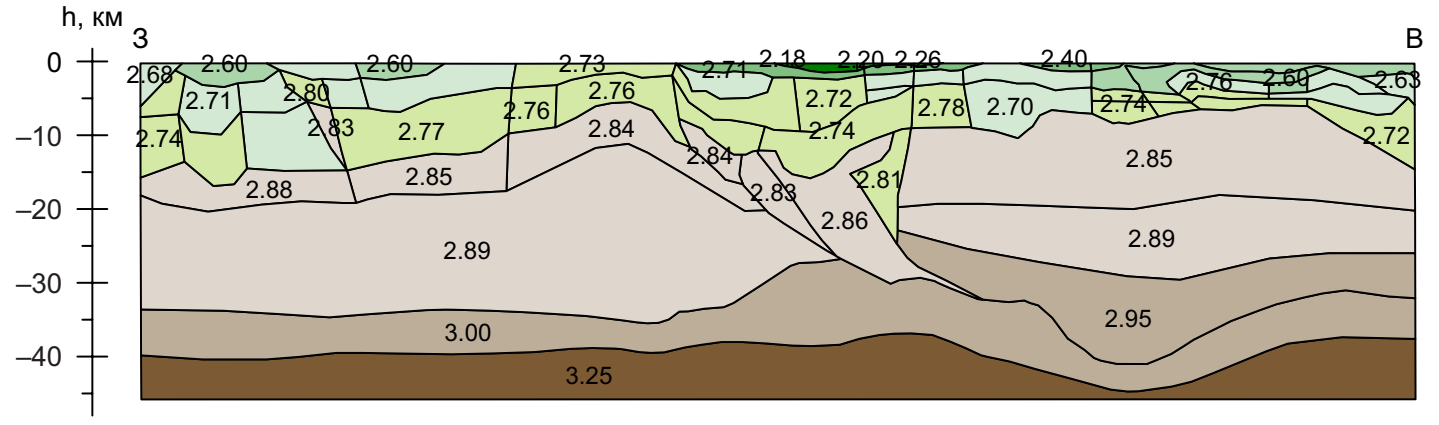

(8)

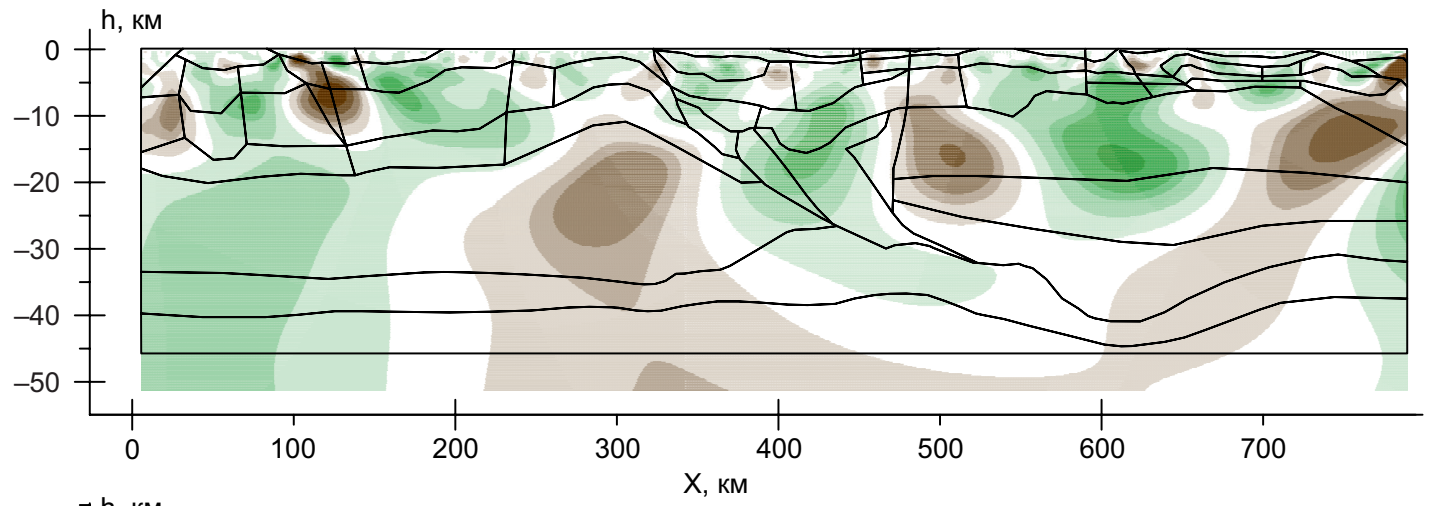

(2)
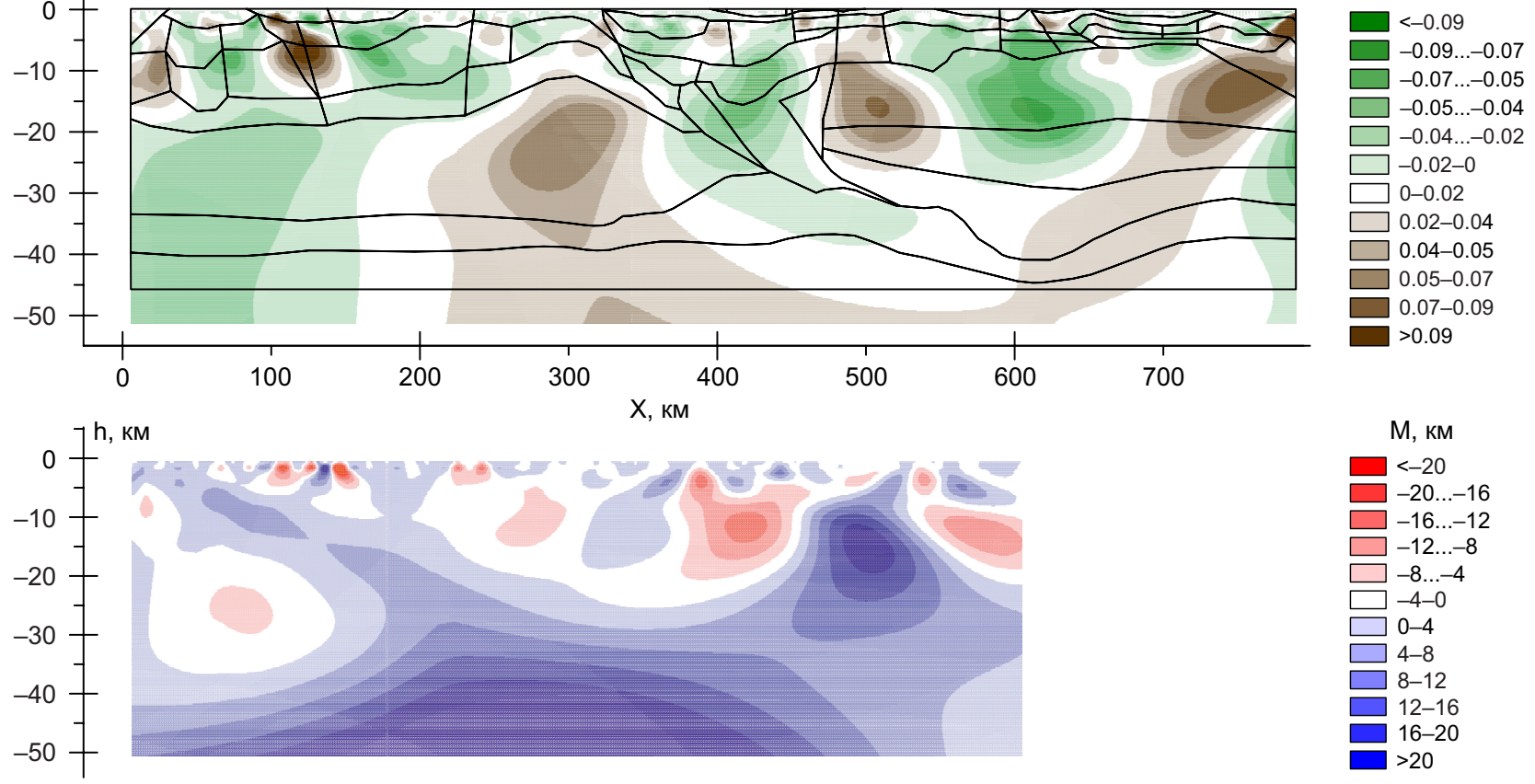

(d)

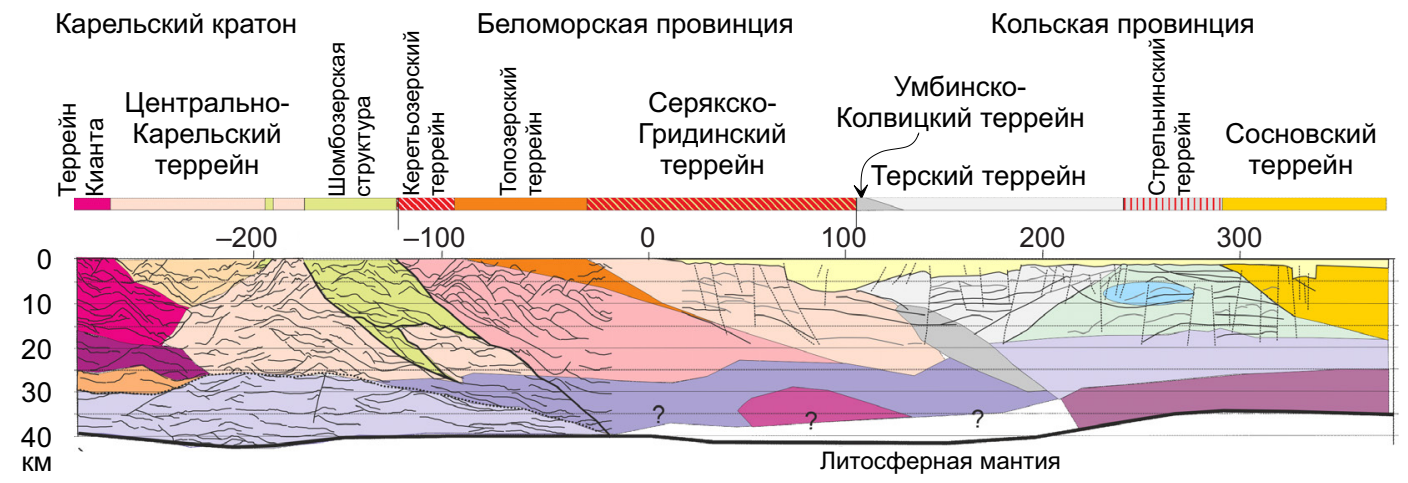

Рис. 6. Геолого-геофизические модели по профилям 4В (Кемь - Калевала) и 3-АР (Кемь - горло Белого моря).

$(a)$ - графики наблюденных и модельных полей; (б) - плотностная блоковая модель на основе сейсмических данных; (в) распределение эффективной плотности; (2) - распределение магнитных неоднородностей; (d) - геолого-геофизический разрез земной коры.

Fig. 6. Geological-geophysical models for profiles 4B (Kem - Kalevala) and 3-AP (Kem - White Sea strait).

$(a)$ - plots of observed and model fields; (б) - density block model based on seismic data; ( 8 ) - effective density distribution; ( 2 ) distribution of magnetic heterogeneities; $(\partial)$ - geological-geophysical cross-section of the crust. 
(a) $\Delta \mathrm{G}, \mathrm{мГал}$

$\Delta \mathrm{T}, 100 \cdot \mathrm{HT} л$
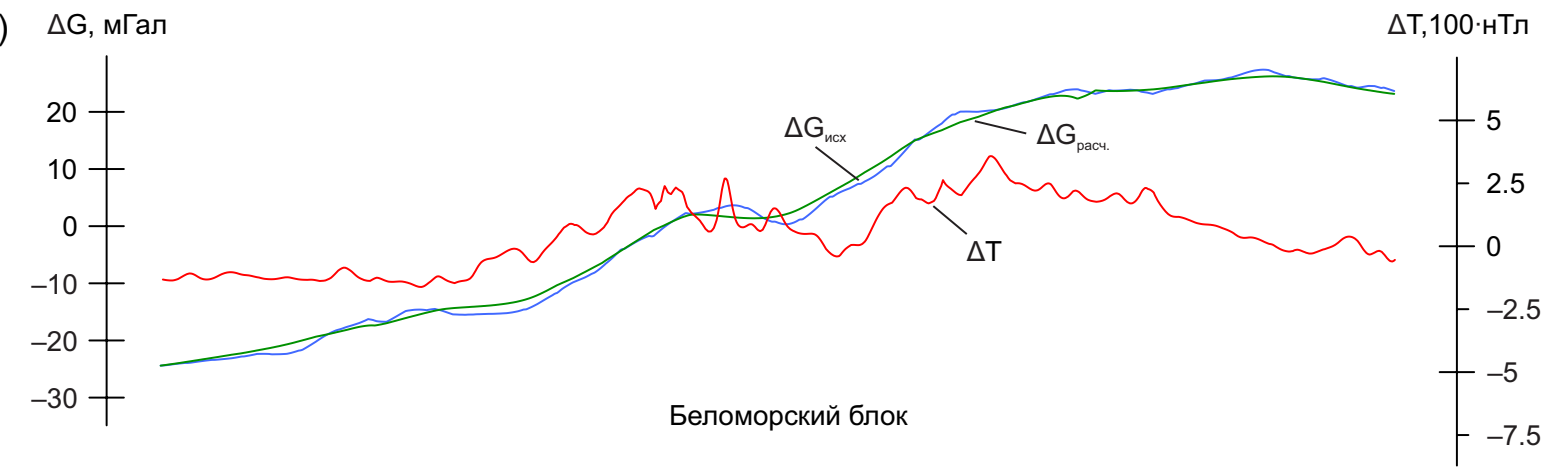

(б)

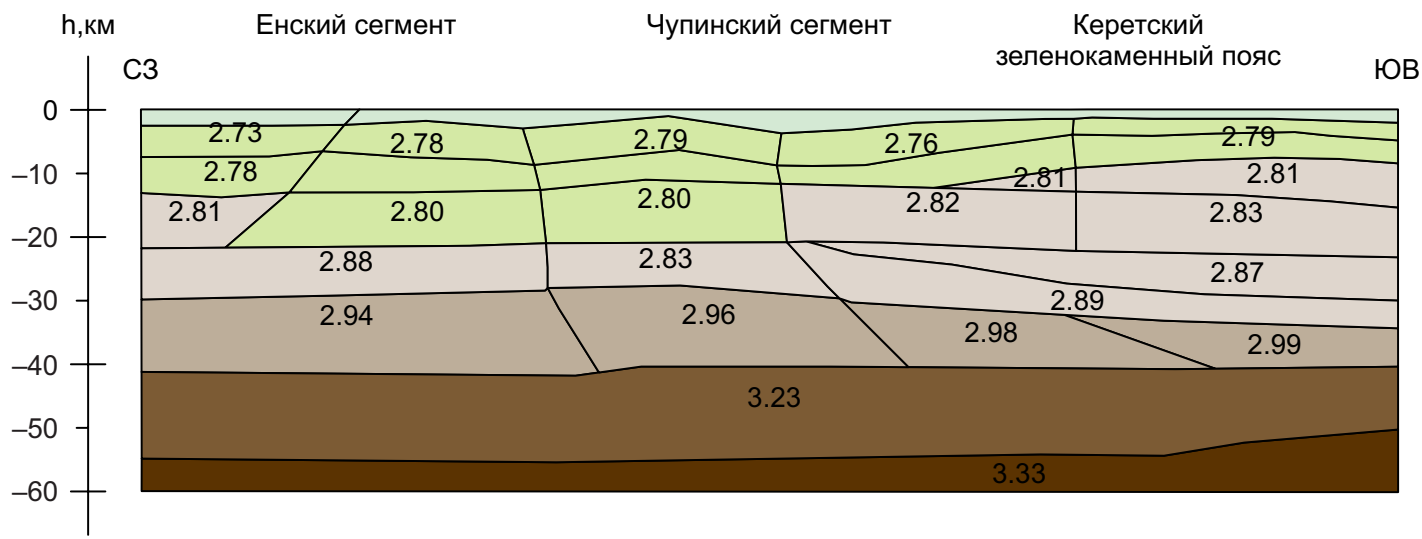

(в)

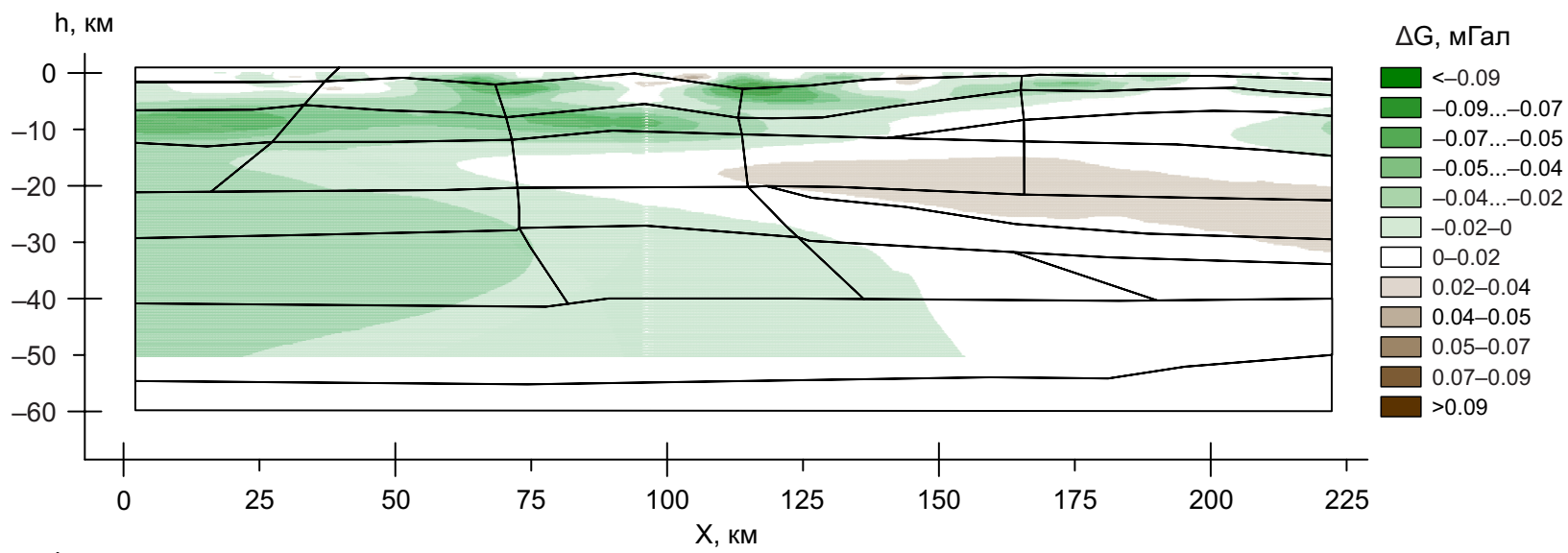

(2)

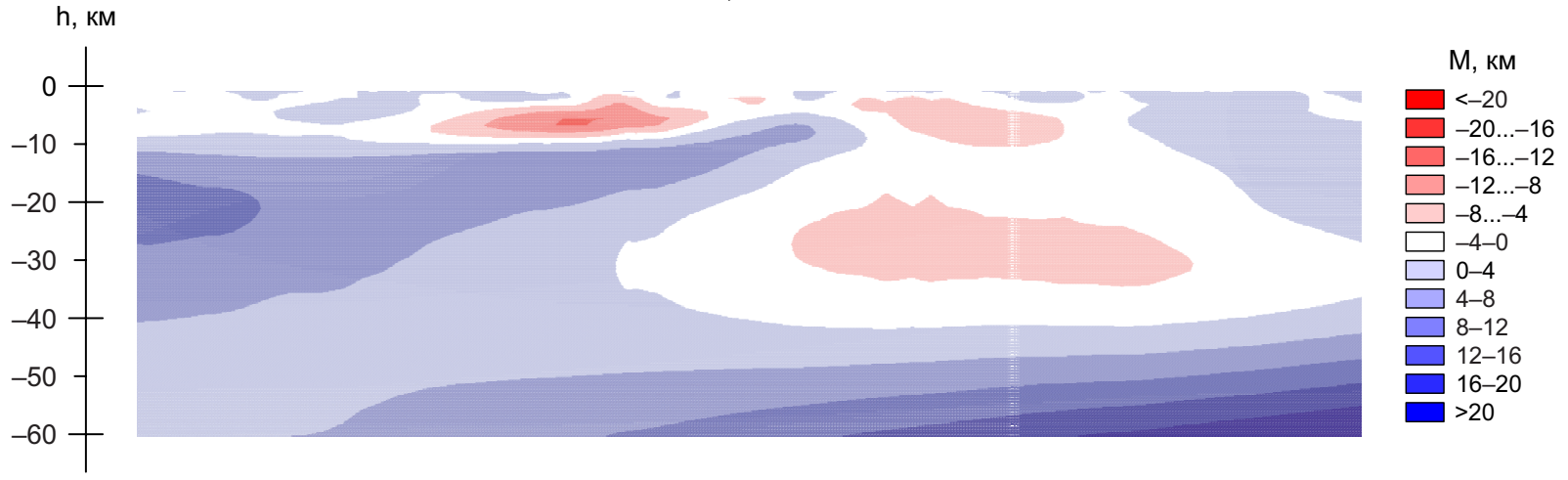

Рис. 7. Плотностная и магнитная модели по сейсмическому профилю Кандалакша - Кемь.

$(a)$ - графики наблюденных и модельных полей; (б) - плотностная блоковая модель на основе сейсмических данных; (в) распределение эффективной плотности; (2) - распределение магнитных неоднородностей.

Fig. 7. Density and magnetic models for the Kandalaksha - Kem seismic profile.

(a) - plots of observed and model fields; (б) - density block model based on seismic data; ( 8 ) - effective density distribution; (2) distribution of magnetic heterogeneities. 


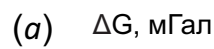

\section{$\Delta \mathrm{T}, 100 \cdot$ нТл}

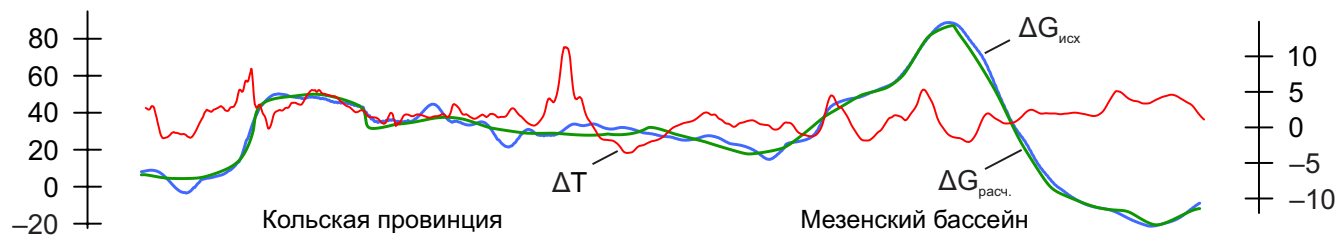

(б)
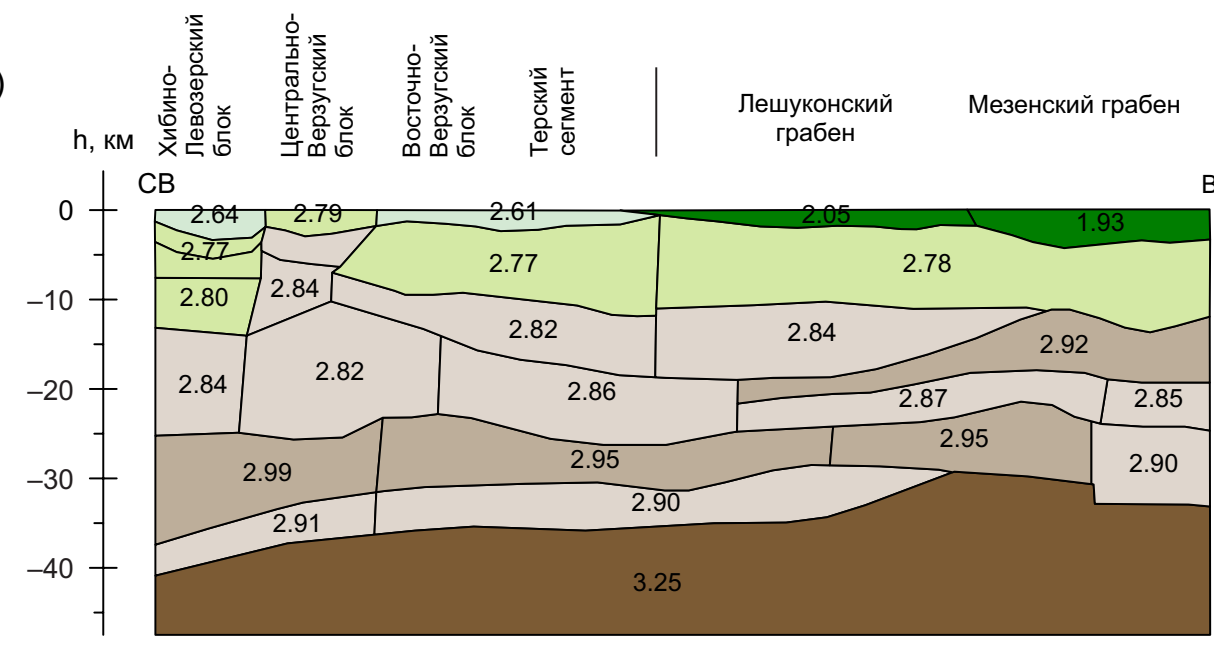

(8)
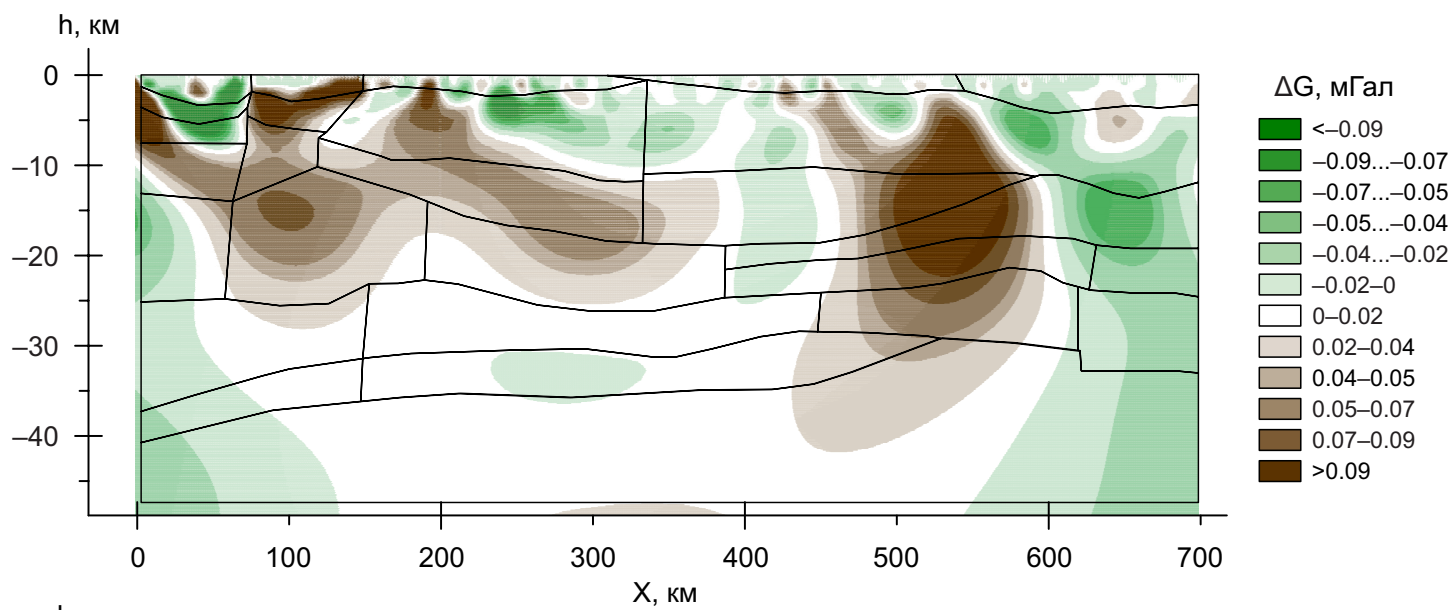

(2)

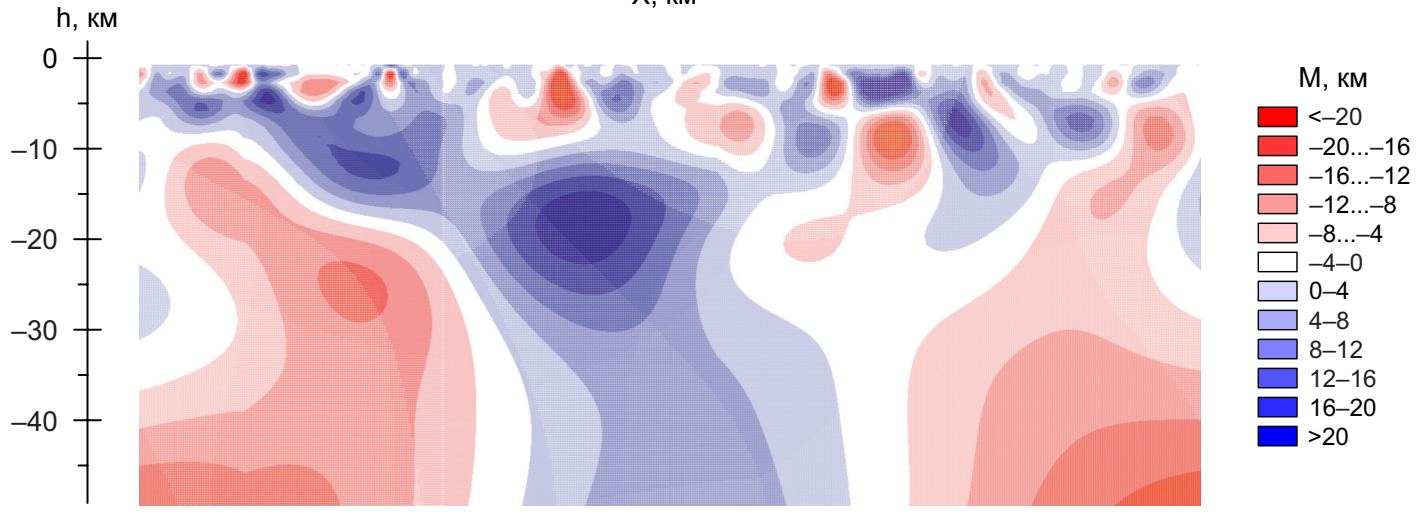

Рис. 8. Плотностная и магнитная модели по участкам сейсмических профилей Кварц 1 и Кварц 2 (Хибины - Варзуга - горло Белого моря - Мезень - р. Цельма).

$(a)$ - графики наблюденных и модельных полей; (б) - плотностная блоковая модель на основе сейсмических данных; (в) распределение эффективной плотности; (2) - распределение магнитных неоднородностей.

Fig. 8. Density and magnetic models for portions of Quartz 1 and Quartz 2 seismic profiles (Khibiny - Varzuga - White Sea strait Mezen - Tselma River).

(a) - plots of observed and model fields; (б) - density and block models based on seismic data; ( 8 ) - effective density distribution; (2) distribution of magnetic heterogeneities. 
(a) $\Delta \mathrm{G}, \mathrm{мГал}$
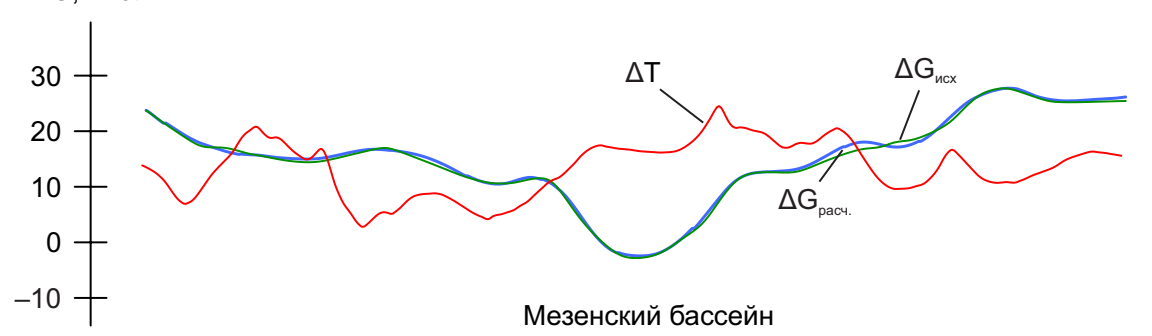

Мезенский бассейн

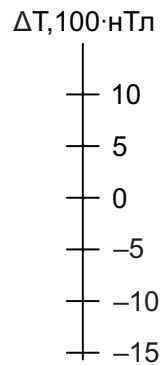

(б)

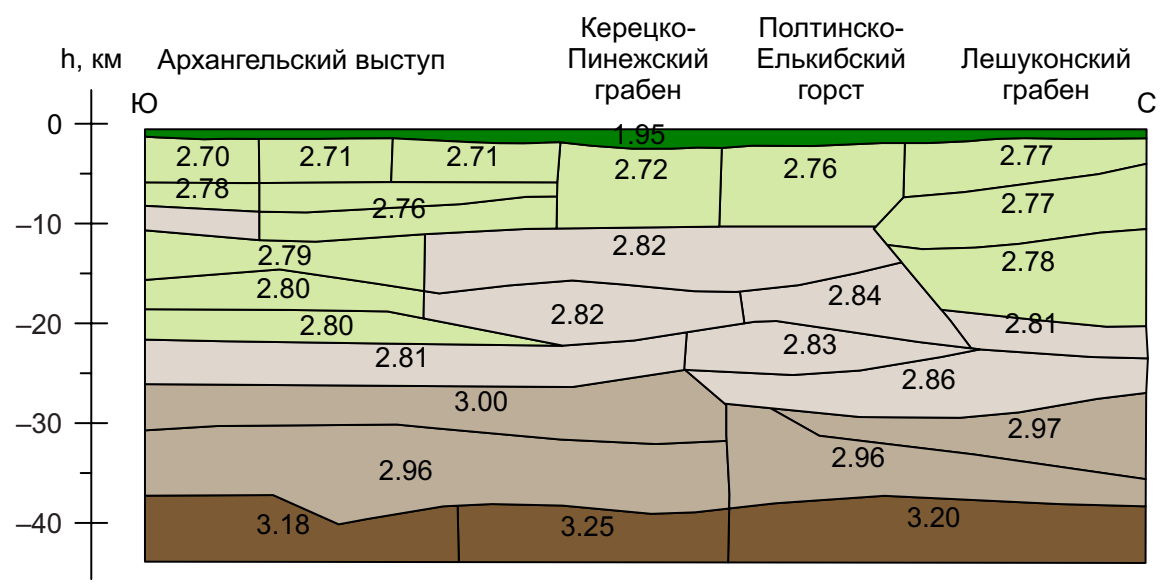

(в)

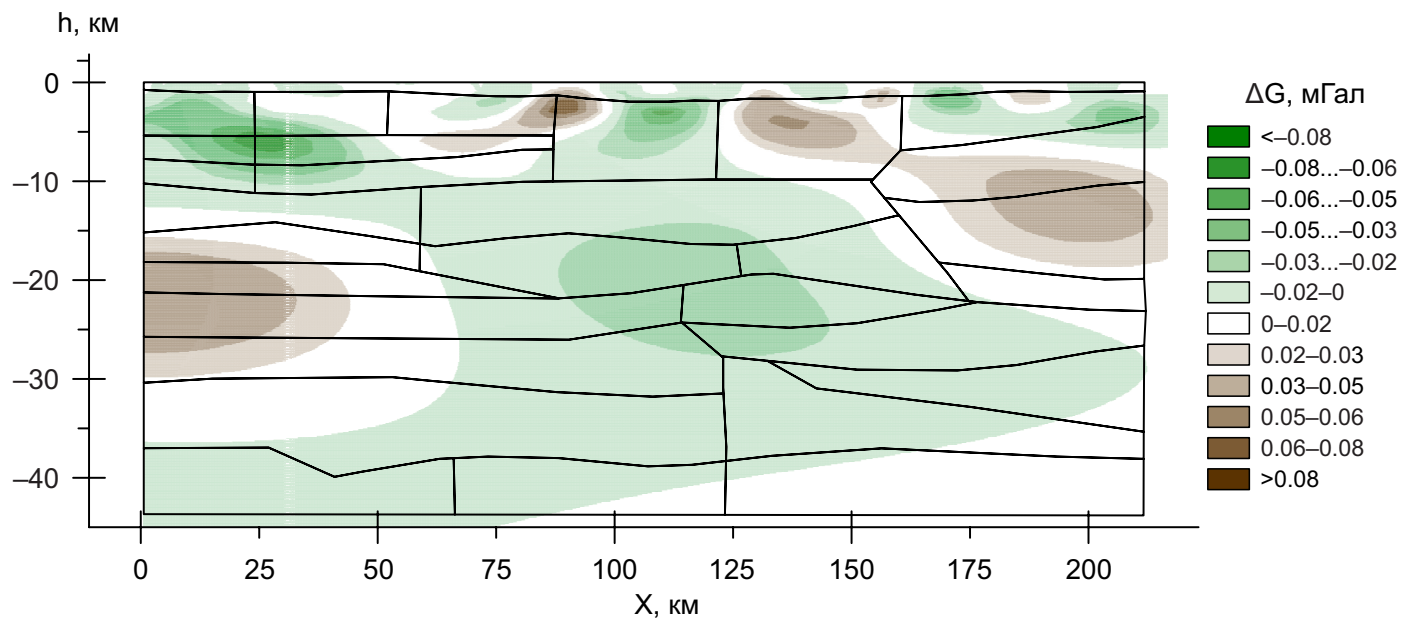

(2)

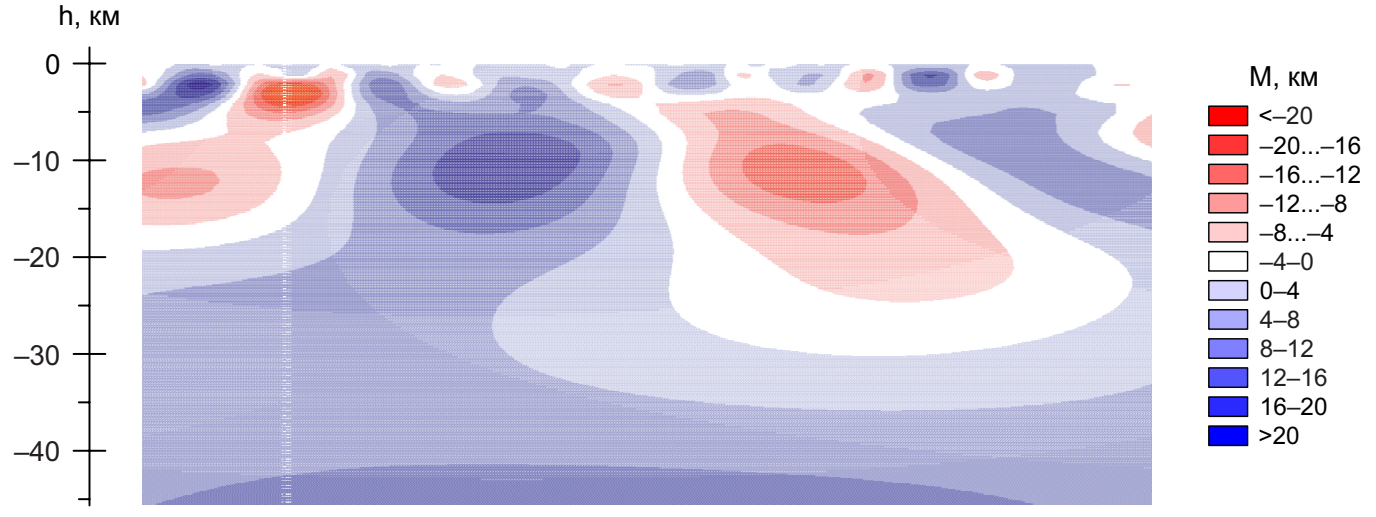

Рис. 9. Плотностная и магнитная модели по участку сейсмического профиля Агат 3 (Усть-Пинега - Белое море).

$(a)$ - графики наблюденных и модельных полей; (б) - плотностная блоковая модель на основе сейсмических данных; (в) распределение эффективной плотности; (2) - распределение магнитных неоднородностей.

Fig. 9. Density and magnetic models for a portion of Agat 3 seismic profile (Ust-Pinega - White Sea).

(a) - plots of observed and models fields; (б) - density block models based on seismic data; ( 8 ) - effective density distribution; ( 2 ) distribution of magnetic heterogeneities. 
На глубине реалогия и кинематика движения горных масс выполаживают разломы к северо-востоку [Baluev et al., 2012].

Результаты сейсмоплотностного моделирования по профилю Калевала - Кемь - горло Белого моря позволяют охарактеризовать земную кору профиля как слоисто-блоковую среду. Блоковое строение подтверждают изменения скорости распространения упругих волн и плотности в горизонтальном направлении, коррелирующие с неоднородностями в разрезе коры. Крупные латеральные неоднородности представлены террейнами, эволюционировавшими в разных геодинамических условиях и совмещенными в ходе коллизионных процессов.

\section{2. Профиль Кандалакша - Кемь}

Согласно рис. 7, кристаллической коре профиля свойственно сложное блоково-слоистое строение. Зоны тектонических нарушений прослеживаются до ПМ. В верхней мантии на глубине около 50 км присутствует отражающая граница $\mathrm{M}_{1}$ [Sharov et al., 2013; Sharov, 2017].

Строение коры вдоль профиля определяют три сегмента с разными плотностными, структурными и скоростными параметрами. Северный (Енский) сегмент (участок профиля 400-430 км) характеризуется большей мощностью земной коры - 40-42 км, верхним градиентным слоем мощностью до 3 км и скоростью продольных волн $V_{p}=5.9$ км/с, мощностью нижней коры, большей, чем в других сегментах, изменяющейся в пределах от 10 до 12 км при $V_{p}=6.95$ км/с. Геофизические измерения фиксируют границу сегмента южнее, чем геологические данные.

В центральном (Чупинском) сегменте (участок профиля 430-550 км) имеет место подъем ПМ в южном направлении от 42 до 40 км, сокращение мощности нижней коры с 10 до 8 км. В средней коре значения скоростей продольных волн уменьшаются до 6.4-6.5 км/с, а в нижней коре, напротив, оказываются около 7.1 км/с, выше, чем в северном сегменте.

В южном (Керетском зеленокаменном поясе) сегменте (участок профиля 550-650 км) мощность коры постоянна - около 40 км, мощность верхнего градиентного слоя уменьшена до 0.7 км, а нижней коры до 7-8 км. Пластовая скорость в нижней коре увеличивается до 7.15 км/с.

\section{3. Фрагмент профилей Кварц 1 и Кварц 2 (Хибины - Варзуга - горло Белого моря - Мезень - р. Цельма)}

Рассматриваемый фрагмент регионального профиля является частью геотраверса Мурманск - Кызыл и пройден в 1983-1985 гг. Центром «Геон». На базе этих профилей в 1991 г. проведено двумерное сейсмоплотностное моделирование земной коры, которое явилось основой для распознавания глубинных геологических структур и прогнозирования геотектонических процессов формирования литосферы [Sharov et al., 2005; Aplonov, Fedorov, 2006]. Данный профиль пересекает различные геотектонические зоны и блоки коры, отличающиеся друг от друга геологическим строением и историей развития. Он ориентирован вдоль важнейших геотектонических элементов и поперек главных структурообразующих глубинных разломов, что позволяет изучать изменение мощности коры в связи с перемещениями по разлому. В результате создается впечатление о сложном внутреннем строении коры и в то же время подтверждается высказанное предположение о горизонтальной расслоенности коры по составу и физическим свойствам.

На основании полученных данных докембрийская кора восточной части Фенноскандинавского щита представляется сложным «пакетом» разновозрастных тектонических элементов, сформировавшихся в различных геологических обстановках. Наиболее отчетливо в геофизических образах распознаются структуры латерального сжатия, растяжения и сопровождающие их крупные магматогенные проявления.

Рифтогенные элементы сквозь коровое растяжение выражаются грабенообразными погружениями фундамента, встречным подъемом ПМ и, как следствие, локальным утонением консолидированной коры. Амплитуда прогибания фундамента составляет 1-2 км. Подъем ПМ под грабенами не превышает 2-3 км, а под областью обширного прогибания на севере Мезенской синеклизы, где располагается сочленение нескольких рифтовых систем, достигает 5 км (см. рис. 8). Структурные особенности сопровождаются изменениями скоростных и плотностных свойств. Физические свойства верхних горизонтов консолидированной коры в большинстве наблюдаемых случаев изменяются в сторону уменьшения скорости на 0.2 км/с и плотности на 0.1-0.3 г/ $\mathrm{cm}^{3}$, свидетельствуя о тектоническом разрушении кристаллических комплексов. В низах коры происходит как уменьшение сейсмоплотностных параметров, так и их увеличение (см. рис. 8). В последнем случае предполагается проникновение в кору мантийного вещества по зонам дизъюнктивных нарушений. Масштабные магматические насыщения косвенно подчеркиваются поведением сейсмических границ, которые испытывают локальное воздымание над областью тектономагматической переработки.

\section{4. Фрагмент профиля Агат 3 (Усть-Пинега - Белое море)}

Рассматриваемый фрагмент регионального профиля является частью геотраверса Агат 3 и пройден в 1985 г. НПО «Нефтегеофизика». Работы выполнены методикой точечного профилирования с шагом между пунктами регистрации трех компонент смещения почвы от 5 до 10 км и расстоянием между ПВ 30-120 км. На базе профилей Агат проведено двумерное сейсмоплотностное моделирование земной коры, которое явилось основой для распознавания глубинных геологических структур и прогнозирования геотектонических процессов формирования литосферы [Sharov et al., 2005; Aplonov, Fedorov, 2006]. Фрагмент профиля пересекает 
Архангельский выступ на юге и серию горстов и грабенов в центральной и северной части - Керецко-Пинежский, Полтинско-Елькибский и Лешуковский, границы которых отчетливо контролируются аномальным поведением магнитного и гравитационного поля (рис. 9). Он ориентирован поперек главных структурообразующих глубинных разломов на контакте восточной части Кольского и Карельского геоблоков.

На сейсмическом профиле уверенно выделяются границы фундамента (глубина 1-4 км, $\mathrm{V}_{\mathrm{p}}=6.0-6.3 \mathrm{\kappa m} / \mathrm{c}$ ) и Мохоровича (глубина 36-40 км, $\mathrm{V}_{\mathrm{p}}=8.0-8.2 \mathrm{\kappa м} / \mathrm{c}$ ). Основные неоднородности, проявленные в геофизических полях, связаны с верхней и средней корой, в то время как нижняя кора имеет скорость продольных волн 6.8-7.1 км/с и, в целом, характеризуется спокойным характером распределения петрофизических параметров на модельных разрезах.

\section{7. ГЛУБИННОЕ СТРОЕНИЕ ЗЕМНОЙ КОРЫ РЕГИОНА}

На схеме глубинного строения региона с наложенными разломами (рис. 10) цветом выделены крупные тектонические области (геоблоки): Мурманская, Тимано-Канинская, Кольская, Мезенская и Карельская, а также ряд меньших блоков [State Geological Map..., 2009a, 2009b, 2009c]. Мурманский геоблок на Кольском полуострове приурочен к северо-восточной окраине Фенноскандинавского щита. Тимано-Канинский геоблок представлен Канино-Северотиманским мегавалом в составе Тимано-Печерской плиты. Структурно-вещественные комплексы Кольского, Мезенского и Карельского геоблоков представлены комплексами Мезенской синеклизы. Эти геоблоки относят к Русской платформе. Распределение плотностных и магнитных неоднородностей в земной коре, полученное в результате решения 3D обратной задачи, приведено на рис. 11.

\section{1. Мурманский геоблок Кольского полуострова}

Сложен гранитогнейсами и гранитоидами, его рассматривают как позднеархейский кратон возраста 2.72.8 млрд лет. По геофизическим данным считается, что элементы его структуры являются фундаментом Понойского перикратонного прогиба в воронке Белого моря.

\section{2. Тимано-Канинский геоблок}

Расположен в северо-восточной части изучаемой площади. Результаты сейсморазведки и моделирования указывают на двухъярусное (складчатое и кристаллическое) строение его верхней коры. Суммарная мощность осадочного чехла и верхней коры 14-16 км.

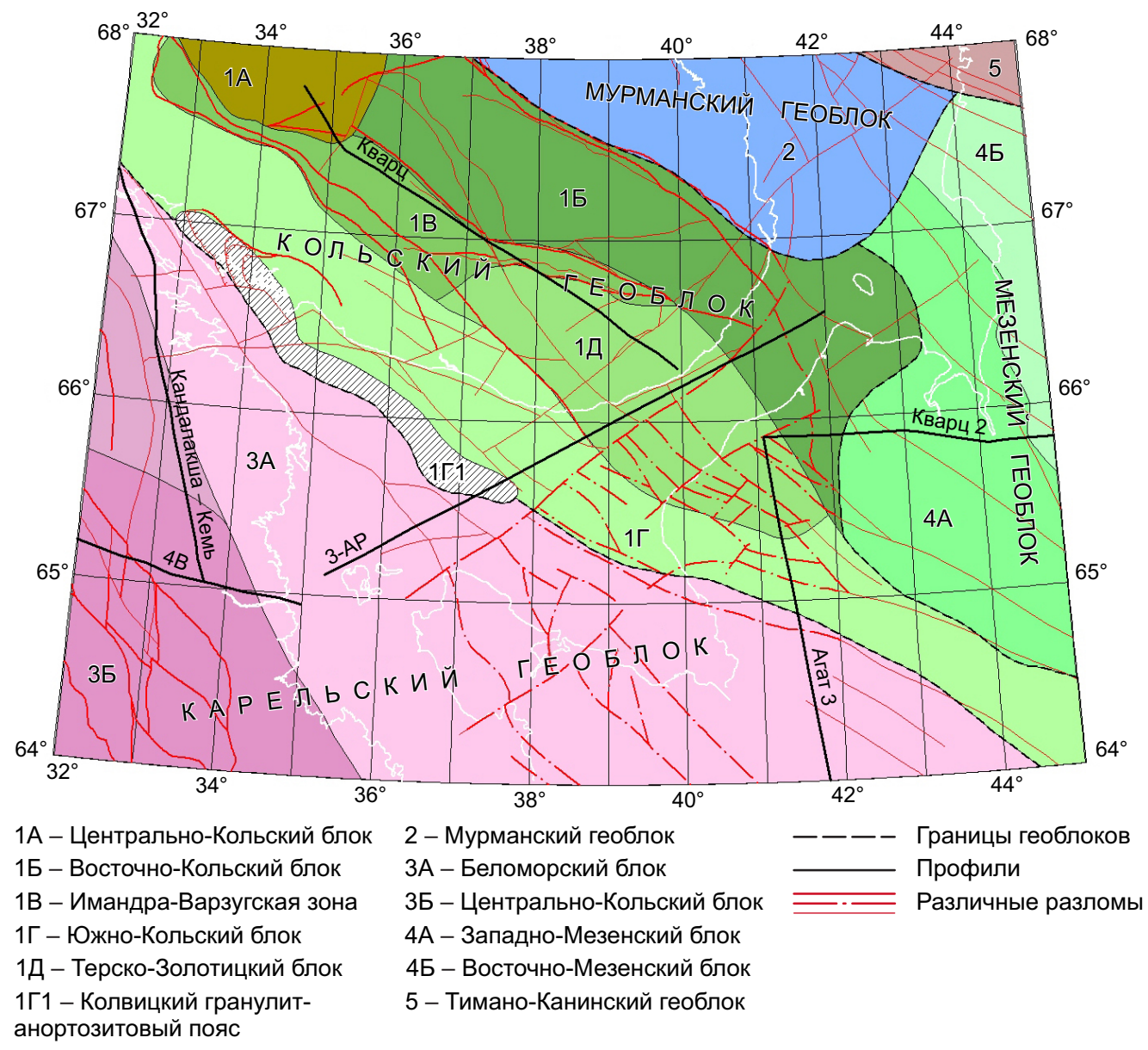

Рис. 10. Схема глубинного строения земной коры Беломорского региона.

Fig. 10. Deep structure of the crust (White Sea region). 
Мощность складчатых пород рифея оценивается в 89 км. Скорости продольных волн в подстилающих рифейских породах кристаллического фундамента повышены, $V_{p}=6.15-6.35$ км/с. Мощность земной коры составляет 38-40 км.

\section{3. Мезенский геоблок}

Находится в пределах Мезенской синеклизы и считается перикратонной частью Восточно-Европейской платформы.

Мезенская синеклиза сформировалась над системой рифейских авлакогенов. Рифты этой континентальной окраины Восточно-Европейской платформы представляют субпараллельные грабенообразные прогибы, имеющие протяженность в несколько сотен километров. Грабены сложены рифейскими образованиями мощностью до 8-10 км, асимметричны и, как правило, сегментированы кулисообразными перемычками. Разделяющие грабены горсты представлены совокупностью разноуровенных поднятий.

В воронке Белого моря и в устье р. Мезень сейсморазведкой установлены две крупные положительные гравитационные аномалии - Мезенский и Конушенский гравитационные максимумы. Этот факт свидетельствует об утонении земной коры в северо-западной части Мезенской синеклизы. Глубина залегания ПМ по данным сейсморазведки здесь составляет 27-30 км, представляя наименьшие значения для Русской плиты. Утонение коры может вызывать внедрение мантийных диапиров. Подтверждением этому является зона пониженных скоростей $\left(V_{p}=0.1-0.3\right.$ км/с), выделенная на глубине 12-22 км. Резкий подъем нижних границ коры может приводить к появлению тел, характеризуемых высокой скоростью распространения упругих волн и

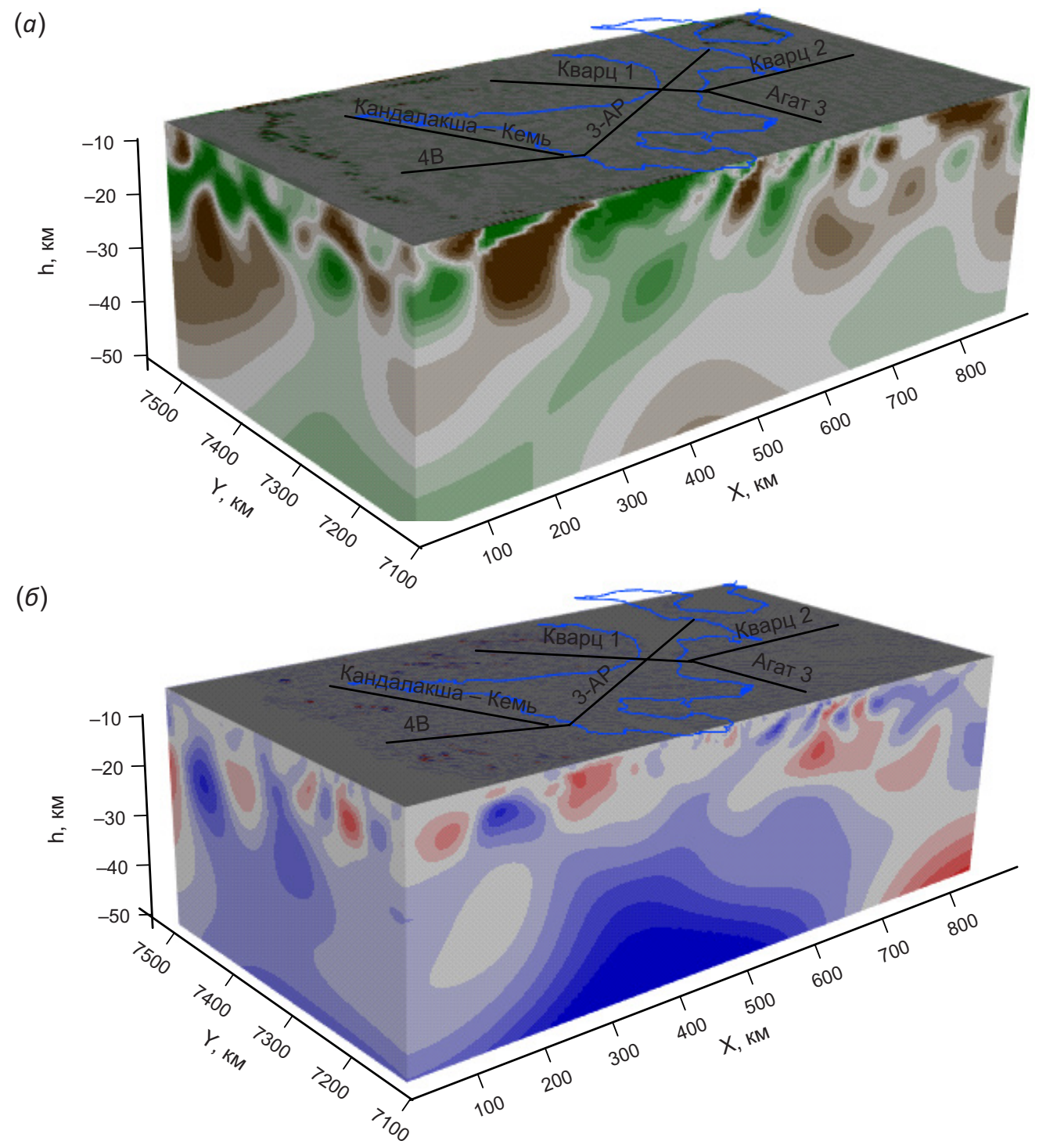

Рис. 11. 3D-модели распределения эффективной плотности ( $a$ ) и магнитных неоднородностей (б) в земной коре Беломорского региона с указанием береговой линии и положения сейсмических профилей.

Fig. 11. 3D models showing effective density distribution ( $a$ ) and magnetic heterogeneities (б) in the crust of the White Sea region. The shoreline and positions of the seismic profiles are shown. 
намагниченностью, дающей положительные аномалии магнитного поля [Erinchek, 2007]. По аномалиям физических полей и мощности осадочного чехла в Мезенском геоблоке выделяют Западно-Мезенский и Восточно-Мезенский блоки.

Для Восточно-Мезенского блока - внешней части перикратона - характерными чертами являются высокие значения граничной скорости продольных волн вдоль ПМ (8.2-8.4 км/с) и большая мощность венд-фанерозойских осадков, достигающая 5-6 км.

У Западно-Мезенского блока, представляющего внутреннюю часть перикратона, мощность венд-палеозойского чехла не превышает 1 км.

\section{4. Кольский геоблок}

Состоит из блоков разного строения, имеющих разную геологическую историю. На Фенноскандинавском щите его рассматривают как гранит-зеленокаменную (гранулит-зеленокаменную) область, испытавшую в архее и раннем протерозое структурно-метаморфические преобразования. Различают Восточно-Кольскую и Южно-Кольскую часть геоблока [Sharov, 2017].

Нижняя часть архейской коры юго-восточной части Восточно-Кольского блока на Кольском полуострове сложена гранитами и гранитогнейсами. По характерным аномалиям геофизических полей структуры блока продолжаются через горло Белого моря. На Зимнем берегу Белого моря их представляет Кулойский выступ и фундамент северо-западного замыкания Лешуконского грабена.

Южно-Кольский блок простирается от побережья Кольского полуострова на акваторию Белого моря, Зимний берег и далее на юго-восток. На юго-востоке с ним связан Керецко-Пинежский грабен, сложенный породами рифея мощностью около 7 км. На Кольском полуострове и Зимнем берегу фундамент блока представлен архейскими мигматит-анатектит-гранитами и гранитогнейсами, частично переработанными в раннем протерозое. Южно-Кольский блок относят к Беломорскому подвижному поясу. Из данных петрогеохимических и изотопных исследований следует, что в палеопротерозое он, вероятно, испытал тектонотермальную переработку.

Граница между Карельской и Кольской тектоническими областями проходит по крупной тектонической зоне (см. рис. 10). На акватории Белого моря зона проявляется локальными положительными аномалиями потенциальных полей. Выделяемые на южном побережье Кольского полуострова в Умбинской и Порьей губах эндербит-чарнокитовый и метаморфические комплексы раннего протерозоя могут быть юго-восточным продолжением коллизионного шва (1.95-1.90 млрд лет) Лапландско-Кольского орогена, разделяющего Карельский и Кольский архейские кратоны.

\section{5. Карельская тектоническая область}

В пределах исследуемой площади представляет Беломорский блок, который Кандалакшско-Онежский разлом делит на две части. По данным сейсморазведки, с глубиной разлом выполаживается и, вероятно, уходит в нижнюю кору. Как и Южно-Кольский блок, Беломорский блок включают в состав Беломорского подвижного пояса - позднеархейской коллизионной структуры, переработанной в раннем протерозое процессами рифтогенеза и орогении. Распространенными архейскими комплексами являются зеленокаменные пояса с наиболее вероятным возрастом 2.7 млрд лет.

\section{8. ЗАКЛЮЧЕНИЕ}

При помощи геоинформационных технологий системы «Интегро» построены согласованные 2D геолого-геофизические модели и 3D-модели распределения плотностных и магнитных неоднородностей строения земной коры Беломорья на всю ее мощность. Полученные путем решения прямых и обратных геофизических задач результаты основаны на известных сейсмических, гравиметрических, магнитометрических, петрофизических и геологических данных.

Используемая в качестве опорной скоростной модели кристаллической коры региона четырехслойная модель аппроксимирует реальную скоростную структуру коры, в единой форме представляет разрезы профилей. В верхнем слое К1 скорости продольных волн составляют 5.9-6.2 км/с, в среднем К2 - 6.3-6.5 км/с, в нижнем, пе реходном коромантийном, К3 - 6.6-6.8 км/с. На грани це $\mathrm{M}$, отделяющей земную кору от верхней мантии, скорость продольных волн изменяется до 8.0-8.2 км/с.

Построенные по детально отработанным профилям ГСЗ плотностные и магнитные 3D-модели демонстрируют мозаично-блоковое строение земной коры. В верхней части коры граница К1 отражает изменения петрофизических свойств пород, в ряде блоков выделяет высокоскоростные внедрения и низкоскоростные пропластки мощностью 3-8 км. Высокоскоростные блоки ассоциированы с геологическими телами повышенной плотности. Для юго-востока Кольского полуострова, отдельных частей Белого моря, северной части Архангельской области глубина границы составляет 13-15 км, тогда как в остальной части мощность верхней коры достигает от 17 до 20 км. Граница К2, связанная, по-видимому, с изменением реологических свойств пород на больших глубинах, на фоне средних глубин 28-30 км по региону имеет локальные подъемы до 18-20 км в районе геотраверса АР-3 и в Белом море, до 25 км под Мезенской структурой и на Кольском полуострове.

Магнитные модели литосферы получены на основе вывода о расположении изотермической поверхности Кюри глубже границы М, подтверждаемого низкими значениями теплового потока в регионе. Плотностные и магнитные неоднородности в мантии для компенсации наблюдаемых гравитационного и магнитного полей в процессе моделирования не привлекались.

Разработанные модели соответствуют главным элементам строения литосферы, блоковому районированию по типам земной коры. Полученные результаты 
подтверждают современные представления о глубинном строении Беломорья, сформированные в ходе натурных экспериментов, интерпретации и обобщения геолого-геофизических данных, и могут быть применены для детального изучения строения литосферы региона, установления связи верхних горизонтов земной коры с глубинной структурой, выяснения характера геофизических границ, комплексирования с геодинамическими и петрологическими моделями, разработки критериев проведения минерагенических оценок. Способные учитывать влияние регионального фона, они позволяют повысить достоверность детального моделирования геологических объектов. Преимуществом является возможность корректировки моделей по мере включения в них дополнительных данных.

\section{9. БЛАГОДАРНОСТИ}

Авторы благодарны анонимным рецензентам за полезные замечания, которые позволили улучшить отдельные рисунки и уточнить ряд положений статьи.

\section{0. ЛИТЕРАТУРA/REFERENCES}

Aplonov S.V., Fedorov D.L. (Eds), 2006. Geodynamic and Possible Oil and Gas Potential of the Mezensk Sedimentary Basin. Nauka, Saint Petersburg, 319 p. (in Russian) [Геодинамика и возможная нефтегазоносность Мезенского осадочного бассейна / Ред. С.В. Аплонов, Д.Л. Федоров. СПб.: Наука, 2006. 319 с.].

Baluev A.S., Brusilovsky Yu.V., Ivanenko A.N., 2018. The Crustal Structure of Onega-Kandalaksha Paleorift Identified by Complex Analysis of the Anomalous Magnetic Field of the White Sea. Geodynamics \& Tectonophysics 9 (4), 12931312 (in Russian) [Балуев А.С., Брусиловский Ю.В., Иваненко А.Н. Структура земной коры Онежско-Кандалакшского палеорифта по данным комплексного анализа аномального магнитного поля акватории Белого моря // Геодинамика и тектонофизика. 2018. Т. 9. № 4. С. 12931312]. https://doi.org/10.5800/GT-2018-9-4-0396.

Baluev A.S., Zhuravlev V.A., Przhiyalgovsky E.S., 2009. New Data on Structure of the Central Part of the White Sea Paleorift System. Doklady Earth Sciences 427, 891-896. https://doi.org/10.1134/S1028334X09060014.

Baluev A.S., Zhuravlev V.A., Terekhov E.N., Przhiyalgovsky E.S., 2012. Tectonics of the White Sea and Adjacent Areas. The Explanatory Notes to the Tectonic Map of the White Sea and Adjacent Areas, at a Scale of 1:500000. Proceedings of GIN RAS 597. GEOS, Moscow, 104 p. (in Russian) [Балуев A.C., Журавлев В.А., Терехов А.Н., Пржиялговский Е.С. Тектоника Белого моря и прилегающих территорий: Объяснительная записка к Тектонической карте Белого моря и прилегающих территорий масштаба 1:500000 // Труды ГИН РАН. Вып. 597. М.: ГЕОС, 2012. 104 с.].

Cheremisina Ye.N., Finkelstein M.Ya., Lyubimova A.V., 2018. GIS INTEGRO - Import Substitution Software for Geological and Geophysical Tasks. Geoinformatics 3, 8-17 (in Russian) [Черемисина Е.Н., Финкельштейн М.Я., Любимова A.B. ГИС INTEGRO - импортозамещающий программно-технологический комплекс для решения геолого-геофизических задач // Геоинформатика. 2018. № 3. C. 8-17].

Erinchek Yu.M. (Ed.), 2007. Models of the Earth's Crust and Upper Mantle by Deep Seismic Profiling. Materials of the Scientific and Practical Seminar. VSEGEI, Saint Petersburg, 245 p. (in Russian) [Модели земной коры и верхней мантии по результатам глубинного сейсмопрофилирования: Материалы научно-практического семинара / Ред. Ю.М. Эринчек. СПб.: ВСЕГЕИ, 2007. 245 с.].

Glaznev V.N., 2003. Integrated Geophysical Models of the Fennoscandian Lithosphere. "K\&M", Apatity, 244 p. (in Russian) [Глазнев В.Н. Комплексные геофизические модели литосферы Фенноскандии. Апатиты: «КаэМ», 2003. 244 c.].

Kashubin S.N., Petrov O.V., Androsov E.A., Morozov A.F., Kaminsky V.D., Poselov V.A., 2011. Map of Crust Thick Ness of the Circumpolar Arctic. Regional Geology and Metallogeny 46, 5-13 (in Russian) [Кашубин C.Н., Петров О.В., Андросов Е.А., Морозов А.Ф., Каминский В.Д., Поселов В.А. Карта мощности земной коры Циркумполярной Арктики // Региональная геология и металлогения. 2011. № 46. С. 5-13].

Kazanin G.S., Zhuravlev V.A., Pavlov S.P., 2006. Structure of the Sedimentary Cover and Petroleum Capacities of the White Sea. Drilling and Oil 2, 26-28 (in Russian) [Казанин Г.С., Журавлев В.А., Павлов С.П. Структура осадочного чехла и перспективы нефтегазоносности Белого моря // Бурение и нефть. 2006. № 2. С. 26-28].

Kheraskova T.N., Sapozhnikov R.B., Volozh Yu.A., Antipov M.P., 2006. Geodynamics and Evolution of the Northern East European Platform in the Late Precambrian as Inferred from Regional Seismic Profiling. Geotectonics 6, 33-51 (in Russian) [Хераскова Т.Н., Сапожников Р.Б., Волож Ю.А., Антипов М.П. Геодинамика и история развития севера Восточно-Европейской платформы в позднем докембрии по данным регионального сейсмического профилирования // Геотектоника. 2006. № 6. С. 33-51].

Kutinov Y.G., Chistova Z.B., Polyakova E.V., Mineev A.L., 2019. Numerical Simulation of Topography to Predict Areas Prospective for Oil and Diamonds. Actual Problems of Oil and Gas 1 (24), 26 (in Russian) [Кутинов Ю.Г., Чистова З.Б., Полякова Е.В., Минеев А.Л. Цифровое моделирование рельефа для прогноза площадей, перспективных на нефть и алмазы // Актуальные проблемы нефти и газа. Вып. 1 (24). 26 с.]. https://doi.org/10.29222/ipng.20785712.2019-24.art8.

Lisitsyn A.P., Nemirovskaya I.A., Shevchenko V.P., Vorontsova V.G., 2017. The White Sea System Scientific World. Vol. 4. The Processes of Sedimentation, Geology and History. Moscow, 1030 p. (in Russian) [Лисицын А.П., Немировская И.А., Шевченко В.П., Воронцова В.Г. Система Белого моря: Процессы осадкообразования, геология и история. М.: Научный мир, 2017. Т. 4. 1030 с.].

Mitrofanov F.P., Sharov N.V., Zagorodny V.G., Glaznev V.N., Korja A.K., 1998. Crustal Structure of the Baltic Shield along the Pechenga-Kostomuksha-Lovisa Geotraverse. International Geology Review 40 (11), 990-997. https://doi.org/ 10.1080/00206819809465250. 
Sapozhnikov R.B., 2003. Efficiency of CDP Seismic Survey in the Study of the Geological Structure of the Mezen Syneclise. Exploration and Subsoil Protection 5, 32-35 (in Russian] [Сапожников Р.Б. Эффективность сейсморазведки МОВ ОГТ при изучении геологического строения Мезенской синеклизы // Разведка и охрана недр. 2003. № 5. C. 32-35].

Sharov N.V. (Ed.), 2004. Deep Structure and Seismicity of the Karelian Region and Its Margins. KarRC RAS, Petrozavodsk, 353 p. (in Russian) [Глубинное строение и сейсмичность Карельского региона и его обрамление / Ред. Н.В. Шаров. Петрозаводск: КарНЦ РАН, 2004. 353 с.].

Sharov N.V., 2017. Lithosphere of Northern Europe: Seismic Data. KarRC RAS, Petrozavodsk, 173 p. (in Russian) [Шаров Н.В. Литосфера по северной Европе по сейсмическим данным. Петрозаводск: КарНЦ РАН, 2017. 173 с.].

Sharov N.V., Mitrofanov F.P., Verba M.L., Gillen K. (Eds), 2005. Lithospheric Structure of the Russian Barents Region. KarRC RAS, Petrozavodsk, 318 p. (in Russian) [Строение литосферы российской части Баренц-региона / Ред. Н.В. Шаров, Ф.П. Митрофанов, М.Л. Верба, К. Гиллен. Петрозаводск: КарНЦ РАН, 2005. 318 с.].

Sharov N.V., Slabunov A.I., Isanina E.V., Krupnova N.A., Pozhilenko V.I., Rakitov V.A., 2013. Seismogelogical Section of the Earth Crust of the North Karelia along the Profile Kandalaksha - Kem. Geophysical Journal 35 (1), 88-99 (in Russian) [Шаров Н.В., Слабунов А.И., Исанина Э.В., Крупнова Н.А., Пожиленко В.И., Ракитов В.А. Сейсмогеологический разрез земной коры Северной Карелии по профилю Кандалакша - Кемь // Геофизический журнал. 2013. T. 35. № 1. C. 88-99].

Sharov N.V., Slabunov A.I., Isanina E.V., Krupnova N.A., Roslov U.V., Chipzova N.I., 2010. Seismological Cross-Section of the Earth's Crust along the Profile DSS - CMP "Land Sea" Kalevala - Kem' - the White Sea Neck. Geophysical Journal 32 (5), 21-34 (in Russian) [Шаров Н.В., Слабунов А.И., Исанина Э.В., Крупнова Н.А., Рослов Ю.В., Щипцова Н.И. Сейсмический разрез земной коры по профилю ГСЗ-ОГТ «Суша-море» Калевала - Кемь - горло Белого моря // Геофизический журнал. 2010. Т. 32. № 5. С. 21-34].
State Geological Map of the Russian Federation, 2009a. Baltic Series. Scale 1:1000000. Sheet Q-(35), 36 (Apatity). Explanatory Note. VSEGEI, Saint Petersburg, 487 p. (in Russian) [Государственная геологическая карта Российской Федерации. Серия Балтийская. Масштаб 1:1000000. Лист Q-35, 36 (Апатиты). Объяснительная записка. СПб.: ВСЕГЕИ, 2009a. 487 c.].

State Geological Map of the Russian Federation, 2009b. Baltic Series. Scale 1:1000000. Sheet Q-37 (Arkhangelsk). Explanatory Note. VSEGEI, Saint Petersburg, 338 p. (in Russian) [Государственная геологическая карта Российской Федерации. Серия Балтийская. Масштаб 1:1000000. Лист Q-37 (Архангельск). Объяснительная записка. СПб.: ВСЕГЕИ, 2009b. 338 c.].

State Geological Map of the Russian Federation, 2009c. Mezen series. Scale 1:1000000. Sheet Q-38 (Mezen). Explanatory Note. VSEGEI, Saint Petersburg, 350 p. (in Russian) [Государственная геологическая карта Российской Федерации. Серия Мезенская. Масштаб 1:1000000. Лист Q-38 (Мезень). Объяснительная записка. СПб.: ВСЕГЕИ, 2009c. 350 c.].

Tsibulua L.A., Levashkevich V.G., 1992. Terrestrial Heat Flow in the Barents Sea Region. KSC RAS, Apatity, 115 p. (in Russian) [Цыбуля Л.А., Левашкевич В.Г. Тепловое поле Баренцевоморского региона. Апатиты: КНЦ РАН, 1992. 115 c.].

Zhuravlev V.A., 2007. The Crustal Structure of the White Sea Region. Prospect and Protection of Mineral Resources 9, 22-26 (in Russian) [Журавлев B.А. Структура земной коры Беломорского региона // Разведка и охрана недр. 2007. № 9. C. 22-26].

Zhuravlev V.A., Shipilov E.V., 2007. New Data on the Tectonics and Structure of the Sedimentary Cover of the White Sea Rift System. Doklady Earth Sciences 417, 1337-1341. https://doi.org/10.1134/S1028334X07090103.

Zhuravlev V.A., Shipilov E.V., 2008. Structure of the Basins of the White Sea Rift Systems. Oceanology 48 (1), 123-131 (in Russian) [Журавлев В.А., Шипилов Э.В. Строение бассейнов Беломорской рифтовой системы // Океанология. 2008. Т. 48. № 1. С. 123-131]. 